\title{
U źródeł polityki generał-gubernatora wileńskiego hrabiego Michaiła Nikołajewicza Murawjowa wobec kwestii chłopskiej i osadnictwa rosyjskiego na Litwie (1863-1865)
}

Od pierwszych miesięcy panowania Aleksandra II kwestia chłopska zajmowała elity rządzące w Imperium Rosyjskim. Ogłoszona przez cesarza, podczas spotkania z marszałkami powiatowymi i gubernialnymi w Moskwie w marcu 1856 r., konieczność wprowadzenia zasadniczej zmiany ustroju społecznego w rosyjskiej wsi, opartej w szczególności na zniesieniu zawisłości poddańczej, spotkała się z chłodnym i w gruncie rzeczy nieprzychylnym stanowiskiem uczestników tego wydarzenia. Zresztą nie tylko szlachta moskiewska, obawiająca się osłabienia swej pozycji, ale również liczne grono konserwatywnie zorientowanych na sprawy społeczne dygnitarzy i oficjeli rosyjskich, w tym minister spraw wewnętrznych Sergiej Łanskoj, widzieli w nadchodzących zmianach zaprzeczenie stabilności, tak przecież oczekiwanej po rosyjskiej klęsce w wojnie krymskiej ${ }^{1}$. Natomiast za przygotowanie projektów wpisujących się w wyznaczony kierunek zmian, zakładający utworzenie grupy włościan-właścicieli, odpowiedzialni byli, określani mianem biurokratów, Nikołaj Miliutin i Jakow Rostowcew ${ }^{2}$.

${ }^{1}$ D. Szpoper, Sytuacja włościan w guberniach zabranych Cesarstwa Rosyjskiego w okresie poprzedzającym reforme chtopska Aleksandra II z 19 lutego 1861 roku-aspekt polityczno-prawny, „Roczniki Dziejów Ruchu Ludowego” (2002), nr 32, s. 250-251.

2 A. Dżiwielegowa, Nikołaj Aleksiejewicz Miliutin, [w:] Wielikaja rieforma. Russkoje obszczestwo i kriestianskij wopros w proszłom i nastojaszczem, kniga wtoraja, toma IV(prodołżenije) - VI, Moskwa 2012, s. 294; zob. też: L. Bazylow, Historia Rosji, Wrocław 1975, s. 321; I. Isajew, Istorija gosudarstwa i prawa Rossiji. Institutiones, Moskwa 2002, s. 417. 
Trzeba również podkreślić, iż w gronie „zaciekłych przeciwników” zniesienia poddaństwa w Imperium Rosyjskim znalazł się Michaił Murawjow³ ${ }^{3}$ Ten rosyjski działacz państwowy, przed zajęciem stanowiska generał-gubernatora wileńskiego ${ }^{4}$, objął kierownictwo nad ministerstwem dóbr państwowych (ministerstwo gosudarstwiennych imuszczestw) w kwietniu 1857 r. i sprawował ten urząd do $1862 \mathrm{r}$. W tym czasie jego decyzjom podlegało administrowanie sprawami związanymi z gospodarką i eksploatacją gruntów należących do skarbu monarchii, włączając w to: tereny orne, znajdujące się we wnętrzu ziemi bogactwa kopalniane oraz lasy i jeziora ${ }^{5}$. Michaił Murawjow, jako minister, nadzorował prace izb dóbr państwowych (pałata gosudarstwiennych imuszczestw). Na czele tych instytucji, stanowiących część administracji specjalnej państwa, stali zarządzający (uprawlajuszczij) ${ }^{6}$. W ich skład wchodziło także dwóch radców, z których jeden odpowiedzialny był za sprawy gospodarowania ziemią uprawną, drugi zaś zarządzał gruntami leśnymi. W niektórych tego typu instytucjach przewidziano także urząd radcy odpowiedzialnego za opiekę nad zagranicznymi osadnikami. Całość składu personalnego izby uzupełnili niżsi urzędnicy - mierniczowie oraz inżynierowie? ${ }^{7}$.

Z punktu widzenia podejmowanych ówcześnie i w przyszłości przez Michaiła Murawjowa decyzji, istotne wydaje się, iż ministerstwu dóbr państwowych podlegały również sprawy chłopów państwowych, którzy mając formalnie zagwarantowaną opiekę państwa, płacąc podatek od duszy i czynsz, przynależąc do gromad wiejskich (sielskaja obszczina), pracowali na gruntach publicznych. Michaił Murawjow nie krył również swoich krytycznych opinii na temat dziesięcioletnich rządów w ministerstwie sprawowanych przez hrabiego Pawła Kisieljowa ${ }^{8}$. Twier-

\footnotetext{
${ }^{3}$ Minister Michaił Murawjow spotykał się z nieprzychylną postawą części zwolenników opowiadających się za reformą włościańską. To z kolei miało skutkować wystąpieniem po jego stronie „skłonności do lawirowania i intryg”; zob. Z.L.S. [W. Przyborowski], Historia dwóch lat. 1861-1862. Część wstępna 1856-1860, t. I, Kraków 1892, s. 70; zob. też: Uprawlenczeskija elita Rossijskoj impierii. Istorija ministierstw. 1802-1917, red. B. Ananicz, R. Ganielin, W. Pleszkow, A. Sokołow, A. Camutali, W. Czernucha, Sankt-Peterburg 2008, s. 381.

${ }^{4}$ W latach 1827-1835 Michaił Murawjow zajmował w administracji rosyjskiej na północno-zachodnich krańcach Imperium następujące stanowiska: wicegubernatora witebskiego, gubernatora mohylewskiego oraz gubernatora grodzieńskiego; zob. A. Miłowidow, Miery prinjatyje grafom M. N. Murawiewym k ograżdieniju prawosławnago nasieljenija ot latino-polskoj propagandy w Siewiero-zapadnom kraj, Wilno 1900, s. 6.

${ }^{5}$ L. Szepeliow, Czinownyj mir Rossiji XVIII - naczało XX w., Sankt Peterburg 2001, s. 21.

${ }^{6} \mathrm{Z}$ chwilą objęcia stanowiska generał-gubernatora wileńskiego przez Michaiła Murawjowa funkcję zarządzającego Izbą Dóbr Państwowych w Wilnie sprawował Nikołaj Kidoszenkow; zob. Pamiatnaja knizka wilenskoj gubiernii na 1863 god, czast pierwaja, Wilno 1863, s. 39.

${ }^{7}$ L. Szepeliow, Aparat wtasti w Rossiji: epocha Aleksandra I i Nikołaja I, Sankt Peterburg 2007, s. 393.

${ }^{8}$ Uprawlenczeskija elita Rossijskoj impierii..., s. 391.
} 
dził, iż działalność jego poprzednika miała charakter wyłącznie „teoretyczny”, podczas gdy powinna być ona zastąpiona decyzjami wywołującymi praktyczne skutki. Podkreślał zarazem, iż polityka ministerstwa musiała zostać nakierowana na wprowadzenie zasad przyjętych w zarządzaniu majątków udzielnych - stanowiących własność rodziny panującej9.

Biorąc pod uwagę tak ogólnie zakreślone cele, nowy minister dóbr państwowych dokonał korekty, wprowadzanej przez hrabiego Pawła Kisieljowa ${ }^{10}$, reformy administrowania gromadami wiejskimi. Zlikwidowano bowiem okręgowe i wiejskie zarządy gromadzkie. W latach 1859-1862 minister Michaił Murawjow podejmował kolejno decyzje o zamknięciu utworzonych przez swego poprzednika gospodarstw doświadczalnych działających w guberniach: tambowskiej, samarskiej, jekaterynosławskiej i wołogodzkiej. Jedną z głównych przesłanek wprowadzanych przez niego zmian była próba zwiększenia efektywności w gospodarowaniu gruntami publicznymi, w tym przede wszystkim zmniejszenie długów ciążących na nieruchomościach należących do skarbu państwa. Działaniami mającymi na celu zapewnienie realizacji powyższej koncepcji została objęta ludność włościańska, która została dodatkowo opodatkowana.

Minister dóbr państwowych opowiadał się również za restrukturyzacją podległego mu urzędu, jak również instytucji działających w jego strukturze. Popierał rozwiązania, zgodnie z którymi z resortu wydzielono państwową hodowlę koni, a także działania podjęte w maju 1859 r. prowadzące do likwidacji departamentu lasów służących do budowy okrętów i włączenie tej jednostki do struktur departamentu leśnego. Także w 1859 r. urzędnicy podlegli ministrowi Michaiłowi Murawjowowi dokonali przeglądu działalności poszczególnych departamentów. Analiza wniosków przeprowadzonej lustracji skłoniła go do podjęcia decyzji o wzmocnieniu departamentu I oraz II odpowiedzialnych - przy uwzględnieniu czynnika przedmiotowego - odpowiednio za opiekę nad chłopami państwowymi oraz za sprawy ustroju ziemskiego, w tym katastralną wycenę gruntów i zarządza-

\footnotetext{
${ }^{9}$ Ibidem, s. 392.

${ }^{10}$ Hrabia Paweł Dmitrjewicz Kisieljow (1788-1872) sprawował urząd ministra dóbr państwowych od dnia 27 grudnia 1837 do dnia 11 lipca 1856 r. Jego rządy w ministerstwie, z jednej strony oceniane były pozytywnie za umiejętne administrowanie i czerpanie dochodów z gruntów należących do skarbu państwa, z drugiej zaś krytykowany był on za brak zdecydowanej reakcji w sprawach nadużyć popełnianych przez podległych mu urzędników wobec włościan państwowych. Hrabia Kisieljow popierał kierunek zmian zakładający zniesienie poddaństwa w Rosji. Dodatkowo w czasie pełnienia przez niego funkcji ministra dóbr państwowych w kierowanym przez niego resorcie służyło wielu późniejszych twórców włościańskiego ustawodawstwa z 1861 r.; zob. ibidem, s. 383-384; zob. też: S. Knjazkow, Graf P. D. Kisieliew i rieforma gosudarstwiennych kriestian, [w:] Wielikaja rieforma. Russkoje obszczestwo i kriestianskij wopros w proszłom i nastojaszczem, kniga pierwaja, toma I-IV, Moskwa 2012, s. 565.
} 
niem dobrami nieruchomymi należącymi do skarbu państwa ${ }^{11}$. Istotne wydaje się również, iż początkowo I i II departamentem kierował ten sam urzędnik, późniejszy minister spraw wewnętrznych, hrabia Piotr Wałujew ${ }^{12}$.

$\mathrm{Z}$ czasem Michaił Murawjow, planując przygotowanie własnego projektu reformy włościańskiej, dążył do osłabienia jego pozycji. Tym samym odsunął go od kierowania pracami I departamentu w ministerstwie. Jednak inicjatywa, popierana między innymi przez szefa III Oddziału Kancelarii Własnej Jego Cesarskiej Mości księcia Wasilija Dołgorukiego oraz ministra finansów Aleksandra Kniażewicza, polegająca na wspieraniu bardziej umiarkowanego wariantu zmian ustrojowych w strukturze rosyjskiej wsi, stojącego w opozycji do ostatecznie zaakceptowanego przez cesarza planu reformy chłopskiej, wywołała niechęć Aleksandra II wobec osoby Michaiła Murawjowa. Wydarzenia te stały się również jedną z przyczyn odwołania go, po wejściu w życie reformy włościańskiej, z ministerialnego stanowiska ${ }^{13}$.

Abstrahując nieco od rozwoju kariery polityczno-urzędniczej Michaiła Murawjowa, należy podkreślić, iż w Imperium Rosyjskim w dobie poprzedzającej wybuch powstania styczniowego 1863 r., przyjęto szereg aktów prawnych regulujących status ludności włościańskiej w guberniach północno-zachodnich państwa. W lutym 1856 r. ukazała się zatwierdzona przez cesarza uchwała Komitetu Ministrów, która uprawniała chłopów pracujących na gruntach prywatnych (pomijając kupców oraz chłopów skarbowych), a zgodnie z uchwałą Komitetu Ministrów z dnia 6 marca tego samego roku, także włościan świadczących parcę na gruntach publicznych w guberniach północno-zachodnich (za wyjątkiem guberni kowieńskiej), do otrzymywania, wydawanych bezpłatnie, a zarazem ważnych do dnia 1 listopada 1856 r., paszportów. Dokument ten uprawniał jego posiadacza do przekraczania granic guberni w celu poszukiwania innych miejsc gospodarowania w cudzym majątku. Dodać należy, iż normy prawne o takiej treści miały niwelować skutki występujących w tym czasie klęsk nieurodzaju ${ }^{14}$.

${ }^{11}$ Biorąc pod uwagę czynnik terytorialny, I departament zajmował się sprawami majątków państwowych w guberniach centralnych, zaś II departament w guberniach zachodnich i nadbałtyckich; zob. I. Woronow, Ministierstwo Ziemledielija w epochu Nikolaja I (1837-1856 gg.), „Wiestnik Orenburskogo Gosudarstwiennogo Uniwersitieta" (2013), nr 12, s. 23.

${ }_{12}$ Hrabia Piotr Aleksandrowicz Wałujew (1815-1890) dyrektorem II departamentu w Ministerstwie Dóbr Państwowych został mianowany w dniu 21 IV 1858 r. W tym czasie proponował, aby wprowadzić możliwość wykupu części gruntów państwowych; zob. D. Sziłow, Gosudarstwiennyje diejatieli Rossijskoj impierii. Gławy wysszych cientralnych uczerieżdienij (1802-1917). Biobibłograficzeskij sprawocznik, S.[ankt] Peterburg 2001, s. 108; zob. też: Ju. Zieldicz, Piotr Aleksandrowicz Walujew i jego wriemia, Moskwa 2006, s. 173.

13 Uprawlenczeskija elita Rossijskoj..., s. 392-393.

${ }^{14}$ I. Nikotin, Stoletnij pieriod (1772-1872) ruskogo zakonodatielstwa $w$ wozsojediniennych ot Polszi gubiernijach i zakonodatielstwo o Jewriejach (1649-1876), t. II, Wilno 1886, s. 83. 
W następnym kroku, chłopi państwowi zarówno z guberni centralnych, jak też guberni zachodnich, uzyskali na podstawie ukazu Senatu Rządzącego z dnia 27 grudnia 1856 r. uprawnienie do przechodzenia w stan wolnych ludzi ${ }^{15}$. Senat Rządzący, wydając rozstrzygnięcie w tym zakresie, podkreślił, iż podstawą jego wydania były normy zawarte w tomie IX (o stanach) Zbioru Praw Cesarstwa Rosyjskiego (Swod zakonow Rossijskoj impierii) z 1832 r. Natomiast przyczyną ogłoszenia tego ukazu był wniosek pochodzącego z guberni wileńskiej chłopa z dóbr państwowych Józefa Radzewicza, który wykazywał wolę opuszczenia dotychczasowego miejsca pobytu i przejścia do pozostającego w prywatnych rękach majątku ziemskiego - Ekengrawy ${ }^{16}$ - położonego w guberni kurlandzkiej ${ }^{17}$. Uzyskanie zgody zależne było od decyzji podjętych przez szereg przedstawicieli rosyjskiego aparatu urzędniczego, w tym przez gubernatora, a następnie przez ministra finansów oraz ministra dóbr państwowych ${ }^{18}$.

W 1857 r. w guberniach wileńskiej, grodzieńskiej i kowieńskiej, znajdujących się wówczas pod władzą wileńskiego generał-gubernatora Władimira Nazimo$\mathrm{wa}^{19}$, ustanowiono przepisy przewidujące utworzenie złożonych $\mathrm{z}$ miejscowej

15 Ibidem, s. 83. O statusie politycznym i prawnym wolnych ludzi (jednodworców) zob. H. Mościcki, Wysiedlenie szlachty na Litwie i Rusi przez rzad rosyjski, [w:] H. Mościcki, Pod berłem carów, Warszawa 1924, s. 38-39; L. Zasztowt, Koniec przywilejów - degradacja drobnej szlachty polskiej na Litwie historycznej i prawobrzeżnej Ukrainie w latach 1831-1868, „Przegląd Wschodni. Historia i współczesność Polaków na Wschodzie" (1991), z. 3, s. 628-632; zob. też: D. Beauvois, Walka o ziemię. Szlachta polska na Ukrainie prawobrzeżnej pomiędzy caratem a ludem ukraińskim 1863-1914, Sejny 1996, s. 141-142.

${ }^{16}$ Majątek ziemski Ekengrawy (niem. Jekengraf) położony był w powiecie frydrychsztackim w guberni kurlandzkiej. W latach dwudziestych XIX w. należał do Fryderyka Adama Mikołaja Manteuffla, zaś przed wybuchem powstania styczniowego dobra te dzierżawił sukcesor prawny Andreasa Odina; zob. A. Janicki, Kurlandia w latach 1795-1915. Z dziejów guberni i jej polskiej mniejszości, Gdańsk 2011, s. 667; zob. też: G. Manteuffel, Inflanty, [w:] „Słownik geograficzny Królestwa Polskiego i innych krajów słowiańskich”, red. F. Sulimierski, B. Chlebowski, W. Walewski, t. III, Warszawa 1882, s. 279.

17 O pieriechod gosudarstwiennych kriestian zapadnych i wielikorossijskich gubiernij $w$ czastnyja imienija Ostziejskich gubiernij, 27 XII 1856, Polnoje sobranije zakanow Rossijskoj impierii, t. XXXI, Sankt-Peterburg 1856, s. 1095.

${ }^{18}$ I. Nikotin, op. cit., s. 83.

${ }^{19}$ Władimir Iwanowicz Nazimow (1802-1874) w okresie od 20 X 1840 r. do 6 XII 1841 r. pełnił funkcję przewodniczącego komisji śledczej w Wilnie w sprawie stronników Szymona Konarskiego. W celu objęcia stanowiska generał-gubernatora przybył do Wilna w dniu 21 lutego $1856 \mathrm{r}$. Urząd ten sprawował do dnia 1 maja 1863 r, zaś $16 \mathrm{~V}$ tego samego roku opuścił Wilno. W $1861 \mathrm{r}$. otrzymał złoty medal upamiętniający oswobodzenie włościan od zależności poddańczej. Natomiast za służbę na stanowisku generał-gubernatora wileńskiego odznaczony został - w dniu 1 maja 1863 r. - orderem Świętego Aleksandra Newskiego; zob. D. Sziłow, Ju. Kuzmin, Czleny Gosudarstwiennogo Sowieta Rossijskoj impierii 1801-1906. Biobibłograficzeskij sprawocznik, S.[ankt]-Peterburg 2007, s. 537-539. 
szlachty komitetów gubernialnych (komitetów włościańskich) ${ }^{20}$. Ponadto na mocy tego samego reskryptu zatwierdzonego przez cesarza na imię generał-gubernatora Nazimowa z 20 listopada 1857 r. miała być również utworzona w Wilnie ogólna komisja w sprawie przedkładania projektów i uwag dotyczących położenia ludności chłopskiej. Składała się ona z następujących członków: 1) po jednym z przedstawicieli szlachty każdego powiatu; 2) dwóch ziemian reprezentujących generał-gubernatora i 3 ) przedstawiciela ministra spraw wewnętrznych. Przewodniczącym Komisji ogólnej była osoba wskazywana przez generał-gubernatora z grona jej członków. Komitety gubernialne z jednej strony były odpowiedzialne za wzmocnienie środków ochrony prawa własności prywatnych majątków ziemskich, z drugiej zaś czuwali nad przekazywaniem do użytkowania chłopom pracującym na gruntach należących do szlachty, tak zwanej części udzielnej tych majątków, w celu zabezpieczenia ich materialnego bytu oraz możliwości wypełniania nałożonych na nich powinności, które przyjęły formę obroku lub prac osobistych w majątku ziemiańskim ${ }^{21}$. Jednocześnie generał-gubernator wileński, a także poszczególni gubernatorzy otrzymywali płynące z ośrodków centralnych instrukcje, w myśl których komisja ogólna, jak i poszczególne komitety gubernialne miały zadbać w okresie przygotowań do reformy chłopskiej, aby włościanie nieprzerwanie pozostający $\mathrm{w}$ stosunku poddańczym wobec szlachty, nie poddawali się ,żadnym szkodliwym sugestiom i kłamliwym interpretacjom”22. Ustrojowi i podstawowym zasadom działalności komisji oraz komitetów w guberniach litewskich poświęcone było rozporządzenie ministra spraw wewnętrznych z dnia 21 listopada 1857 r. W myśl norm zawartych w tym akcie, komisje gubernialne miały zakończyć prace nad przygotowaniem projektów i uwag do reformy włościańskiej w terminie sześciu miesięcy. W przypadku uchylania się od powierzonych im zadań lub w razie przekroczenia swych kompetencji generał-gubernator mógł podjąć decyzję o rozwiązaniu tych instytucji i poinformowania o tym ministra spraw wewnętrznych. Wedle ogólnej zasady zatwierdzonej w tym samym akcie prawnym, komitety w swej działalności powinny uwzględniać ewolucyjny tok przygotowywanych zmian. Dodatkowo w okresie przejściowym, trwającym do dwunastu lat, który był ustalany przez komitety, instytucje te miały stać na straży statusu prawnego i materialnego włościan ${ }^{23}$, a także czuwać nad mechanizmami

${ }^{20}$ D. Szpoper, Pomiędzy caratem a snem o Rzeczypospolitej. Myśl polityczna i działalność konserwatystów polskich w guberniach zachodnich Cesarstwa Rosyjskiego w latach 1855-1862, Gdańsk 2003, s. 138-139.

${ }^{21}$ I. Nikotin, op. cit., s. 84.

22 Cyt. za: ibidem, s. 85.

${ }^{23}$ Ibidem, s. 85-87; zob. też: $O$ dopotitietnych prawitach kasatielno sostawa i poriadka diejstwii gubiernskich komitetow, uczierieżdiennych w gubierniach: kowienskoj, wilenskoj i grodnienskoj, i osoboj w gorod Wilna kommisii, dlia sostawlenija projektow położenii ob uluczszenii byta 
rozliczania tak powinności pieniężnych, jak i naturze, ciążących na chłopach pracujących na rzecz właścicieli ziemskich. Komitety gubernialne zainaugurowały swą działalność w lutym 1858 r. ${ }^{24}$

Z korespondencji nadsyłanej z guberni litewskich w 1859 r. do redakcji tygodnika „Wiadomości Polskie” w Paryżu, popierającego linię programową Hotelu Lambert, wyłaniał się obraz kwestii włościańskiej, jako jednej z najpilniejszych do uregulowania spraw społecznych w zaborze rosyjskim ${ }^{25}$. Anonimowy autor relacjonował wówczas: „Pierwszy akt sprawy włościańskiej skończony, obrady komitetowe prawie w całym imperium zamknięte; nasi deputowani wyjechali do Petersburga. Po dwuletniej pielgrzymce myśl reformy wróciła tam, skąd wyszła: zobaczymy co w tym długim przebiegu zyskała". W dalszej części tej samej relacji podkreślono, iż członkowie komitetów gubernialnych w Sankt Petersburgu i Moskwie przyjęli taktykę wyczekiwania, z uwzględnieniem metody, która miała polegać na niewyrażaniu haseł przeciwnych przeprowadzaniu zmian na rosyjskiej wsi, lecz zarazem postulowali, by: „[...] trzymać się biernie, zwlekać, utrudniać i w końcu znudzić cesarza"26. Jednocześnie korespondent wyraził opinię, uwypuklającą wyraźnie rolę szlachty zamieszkującej prowincje zachodnie w działaniach na rzecz powodzenia reformy chłopskiej. Zaznaczał on, iż pomimo sugerowania się przez niektórych przedstawicieli miejscowego ziemiaństwa opiniami płynącymi z Sankt Petersburga, które ,wpłynęły na obrady komitetów [gubernialnych - M.T.], większość szlachty nie broniąc ani zatrzymując poddaństwa [...] chciała u nas w ten sposób swych włościan wyzwolić, aby siebie zarazem od wszelkiego względem nich uwolnić obowiązku" ${ }^{27}$.

Dyskutowana na forum komitetów gubernialnych treść nowych relacji łączących ziemian z włościanami została przedstawiona następująco: „W dzisiejszym stosunku patriarchalnym, pan obowiązany jest opiekować się włościaninem, bronić go wobec prawa, żywić w czasie głodu: otóż te wszystkie ciężary musiałby ustać, odkąd chłop wolny i za pełnoletniego uznany, wchodził z swym panem $\mathrm{w}$ umowę. Popierali przeto zasadę dobrowolnej umowy w przewidzeniu, że chłop, bez gruntu i chaty, pomimo swojej wolności, przystanie, rad nie rad, na wszystkie dawnego pana warunki. Zapobiegając tej nieludzkiej spekulacji, mniejszość

pomszcziczich kriestian sich gubiernii, 21 XI 1857, Polnoje sobranije zakonow Rossijskoj impierii, t. XXXII (dopołnienije), Sankt-Peterburg 1857, s. 6.

${ }^{24} \mathrm{O}$ uprawnieniach i powinnościach chłopów w świetle rozporządzenia ministra spraw wewnętrznych z 21 XI 1857 r.; zob. D. Szpoper, Pomiędzy caratem a snem o Rzeczypospolitej..., s. $138-142$ i $144-145$.

${ }_{25}$ M. Gancewski, Polskie życie narodowe w kraju w latach 1857-1861 w ocenie ,, Wiadomości Polskich” (część 2), „Zeszyty Naukowe Uniwersytetu Jagiellońskiego. Prace Historyczne” (2015), z. 3, s. 430 .

${ }^{26}$ Cyt. za: Koresp.[ondent], Z Litwy, „Wiadomości Polskie” 1 X 1859 (Paryż), nr 40, s. 1.

${ }^{27}$ Cyt. za: ibidem, s. 1-2. 
członków, zazwyczaj młodsza wiekiem, domagała się dla chłopów wolności razem z własnością, i w tym kierunku szli nawet dalej niż rząd zastrzegał, bo chcieli odstąpienia włościanom i zagrody i ornych gruntów"28.

Etap przygotowawczy do reformy włościańskiej ocenił w swym raporcie z 1859 r. minister dóbr państwowych Michaił Murawjow. Wszakże jego opinii nie podlegała gospodarka prowadzona w prywatnych majątkach ziemskich, lecz status prawno-ekonomiczny włościan państwowych na gruntach należących do skarbu państwa $\mathrm{w}$ guberniach północno-zachodnich oraz $\mathrm{w}$ guberniach nadbałtyckich. Minister zaznaczył, iż: „Obfity nadział ziemią, samoistnie nie zabezpiecza dobrobytu ludności w tych miejscach gdzie gleba potrzebuje uprawy i gdzie oprócz tego ustanowione są formy korzystania z ziemi, rozdrobnienie gruntów na działki w postaci pasów i odległości pól od osady, powodują dla gospodarzy szczególne trudności”. Trudności związane z gospodarowaniem państwowymi dobrami ziemskimi potęgowane były przez zjawisko ich zadłużenia. Świadczyły o tym przytoczone przez ministerstwo dane, obowiązujące na dzień 1 stycznia 1856 r. Oficjalne statystyki wskazały, iż w majątkach należących do skarbu monarchii położonych w północno-zachodniej części Imperium, w których chłopom zamieniono robociznę na obowiązek odprowadzania czynszu, wystąpiło zadłużenie sięgające 1967000 rubli2 $^{29}$.

Biorąc pod uwagę kolejne akty regulujące status prawny włościan pracujących na gruntach państwowych położonych w zachodnich prowincjach Imperium, należy wspomnieć o zatwierdzonym przez cesarza w dniu 30 marca 1859 r. raporcie ministra dóbr państwowych. Zgodnie z zawartymi w nim postanowieniami, zostały zmniejszone o połowę należności wynikające z korzystania z lasów na potrzeby socjalno-bytowe. Z tym niemniej zastrzeżeniem, iż o redukcji wysokości opłaty decydował minister, po uwzględnieniu miejscowych warunków ${ }^{30}$.

Zakończenie prac nad reformą włościańską wiązało się z wydaniem manifestu Aleksandra II z dnia 19 lutego 1861 r. ${ }^{31}$ Manifest stanowił sui generis akt wpro-

${ }^{28}$ Cyt. za: ibidem, s. 2.

${ }^{29}$ Cyt. za: Gossudarswiennyj Archiw Rossijskoj Fiedieracji, Moskwa, sygn. F. 811, op. 1, d. 24, rkps, Otcziet ministra gosudarstwiennych imuszczestw [Michaiła] Murawiewa Aleksandru II o diejatielnosti ministierstwa s 17 IV 1857 po 1 I 1859, Sankt-Peterburg 6 IV 1859. Kolekcja Michaiła Murawjowa, k. 31-31v.

${ }^{30}$ I. Nikotin, op. cit., s. 88.

${ }^{31}$ W myśl manifestu z 19 lutego 1861 r. reformą mieli zostać objęci zarówno włościanie w majątkach prywatnych, jak też włościanie w majątkach państwowych. Ukazem z 18 IV 1866 r. Aleksander II określił szczegółowo status prawny włościan państwowych, niemniej, wyłącznie znajdujących się pod opieką izb dóbr państwowych w guberniach „rządzonych na ogólnych zasadach”, a zatem z wyłączeniem guberni zachodnich Cesarstwa Rosyjskiego. Natomiast chłopi państwowi z tych guberni północno-zachodnich otrzymali prawo wykupy ziemi dopiero na mocy rozporządzenia z 28 maja 1867 r.; zob. A. Gradowskij, Naczała russkago gossudarstwiennago prawa, t. I, 
wadzający do całego szeregu bardziej szczegółowych ustaw regulujących ustrój społeczno-gospodarczy na rosyjskiej wsi ${ }^{32}$. Zbiór aktów prawnych zawierał między innymi Ustawę o włościanach uwolnionych od zależności poddańczej (Wysoczajsze utwierżdiennoje położenije ob ustrojstwie dwornych ludiej, wyszedszich iz kriepostnoj zawisimosti) $)^{33}$. W manifeście cesarz podkreślił udział „,rosyjskiej szlachty" w pracach przygotowawczych poprzedzających ustanowienie ustawodawstwa włościańskiego. Monarcha podkreślił, iż: „W komitetach gubernialnych [...] szlachta dobrowolnie zrzekła się praw do osób swych poddanych". Istotą dokonujących się zmian było zagwarantowanie prawa własności majątków należących do szlachty zamieszkującej gubernie zachodnie, przy jednoczesnym uwzględnieniu nadanych włościanom praw, objawiających się uprawnieniem do stałego korzystania z nadziałów gruntów ${ }^{34}$. Nadział gruntu był wydzieloną do korzystania przez włościan częścią nieruchomości należącej do ich właściciela, którym w warunkach społeczno-gospodarczych obowiązujących na północno-zachodnich krańcach Imperium Rosyjskiego był na ogół przedstawiciel, w sensie terytorialnym litewsko-białoruskiej szlachty ${ }^{35}$. W takim razie udzielna część ziemi nie została objęta przynależnym chłopu prawem własności, nie podlegała dziedziczeniu, jak również nie mogła być w inny sposób alienowana przez swego posiadacza $^{36}$. Jednocześnie miała być przekazywana wyłącznie do użytkowania włościanom na czas przejściowy, wynoszący dwa lata, w trakcie którego, zyskiwali oni status włościan czasowo zobowiązanych ${ }^{37}$. W tym samym okresie po ich stronie przewidywano występowanie określonych normami szczegółowymi powinności ${ }^{38}$.

Równie istotna zasada przewidywała, iż włościanie, za zgodą właściciela gruntu, mogli nabyć przekazaną im dotychczas do stałego użytkowania część gruntu. W manifeście cesarskim zastrzegano jednak, iż: „Po takim nabyciu na własność oznaczonej ziemi, włościanie uwolnią się od obowiązków względem

Sankt-Peterburg 1875, s. 302; zob. też: E. Aleksandravičius, A. Kulakauskas, Pod władzq carów. Litwa w XIX wieku, Kraków 2003, s. 234.

32 Treść manifestu została opublikowana zarówno w miejscowej prasie („Kurier Wileński”), jak również w czasopismach ukazujących się w innych dzielnicach zaborczych („Czas”); zob. Najwyższy manifest, „Kurier Wileński” (Wilno) 10 III 1861, nr 20, s. 172-174; zob. też: Rosja, „Czas” 31 III 1861 (Kraków), nr 76, s. 3; Szpoper, Pomiędzy caratem a snem o Rzeczypospolitej..., s. 229.

33 Wysoczajsze utwierżdiennoje położenije ob ustrojstwie dwornych ludiej, wyszedszich iz kriepostnoj zawisimosti, [w:] Krestianskaja rieforma w Rossiji 1861 goda. Sbornik zakonodatielnych aktow, red. K. Sofronenko, Moskwa 1954, s. 83-89.

${ }^{34}$ Cyt. za: Rosja..., s. 3.

35 J. Żenkiewicz, Litwa na przestrzeni wieków i jej powiązania z Polska, Torun 2001, s. 109.

${ }_{36}$ M. Heller, Historia Imperium Rosyjskiego, Warszawa 2009, s. 590.

${ }^{37}$ I. Isajew, Istorija gosudarstwa i prawa Rossiji, Moskwa 2013, s. 429-439.

38 J. Hrycak, Historia Ukrainy 1772-1999. Narodziny nowoczesnego narodu, Lublin 2000, s. 76. 
obywateli co do ziemi wykupionej, i wejdą stanowczo do stanu swobodnych włościan-właścicieli" ${ }^{39}$. Dalsze postanowienia wynikające z treści tego dokumentu, stanowiące fundament wdrażanej reformy i uwalniające chłopów od zależności poddańczej, nakazywały utworzyć w każdej guberni urzędy do spraw włościańskich, którym powierzono „wyższe zawiadowanie sprawami gmin włościan, mieszkających w majątkach obywatelskich".

W celu rozstrzygania sporów wynikających z procesów wdrożenia postanowień reformy włościańskiej wyznaczono w powiatach pośredników pojednawczych (mirownyje posredniki), a także złożone z nich zjazdy pośredników pojednawczych (ujezdnyje mirowyje sjezdy). Postanowiono także, że dla każdej gminy wiejskiej bądź prywatnego majątku spisany zostanie list nadawczy (ustawnaja gramota), który następnie miał być zweryfikowany i zatwierdzony. Spisywanie listów nadawczych jawiło się jako operacja stanowiąca jeden z kluczowych czynników powodzenia reformy włościańskiej, gdyż z ich treści wynikała przede wszystkim wielkość areału oddanemu chłopu do stałego użytkowania oraz powiązane $\mathrm{z}$ tym uprawnieniem ustalone powinności odprowadzane na rzecz dworu ${ }^{40}$. Zalecono zarazem, aby listy nadawcze zostały zatwierdzone, indywidualnie dla każdego majątku, w okresie dwóch lat od momentu wejścia w życie tych unormowań. Manifest Aleksandra II z 19 lutego 1861 r. uregulował także, na zasadzie intertemporalności, kwestię dotyczącą utrzymania „nadzoru nad porządkiem” i „prawa sądu i wyrokowania”. Oba uprawnienia zagwarantowano właścicielom majątków ziemskich, którzy mogli z nich korzystać wobec zamieszkującej je ludności chłopskiej ${ }^{41}$.

Po wejściu w życie ustawodawstwa włościańskiego w 1861 r. pojawiły się liczne akty prawne doprecyzowujące lub czasowo regulujące stosunki prawno-gospodarcze na linii „wieś - dwór”. Ustanawiano je z uwzględnieniem zarówno właściwości rzeczowej, jak i miejscowej. W dniu 7 maja 1861 r. na mocy zatwierdzonego przez cesarza stanowiska Głównego Komitetu do Spraw Włościańskich potwierdzono wymiar wypełnianej przez włościan barszcziny (pańszczyzny) w powiecie dyneburskim, drysieńskim, lucyńskim i rzeżyckim (gubernia witebska). Jednocześnie przyjęto, iż określony tymi normami rozmiar powinności obowiązywał nie krócej niż do czasu zatwierdzenia miejscowych listów nadaw$\operatorname{czych}^{42}$. Z kolei w dniu 11 maja $1861 \mathrm{r}$. w myśl zatwierdzonego przez cesarza stanowiska Głównego Komitetu do Spraw Włościańskich przyjęto objaśnienia do niektórych norm - regulujących zasady wykonywania powinności chłopskich na

\footnotetext{
39 Cyt. za: Rosja..., s. 3.

40 D. Szpoper, Pomiędzy caratem a snem o Rzeczypospolitej..., s. 226.

${ }^{41}$ Rosja..., s. 3; zob. też: ibidem, s. 227.

42 I. Nikotin, op. cit., s. 88.
} 
gruntach oddalonych powyżej czterech wiorst od wsi - Ustawy miejscowej o terytorialnym urzadzeniu włościan osiadlych na obywatelskich ziemiach $w$ guberni: wileńskiej, grodzieńskiej, kowieńskiej, mińskiej i części witebskiej ${ }^{43}$.

Przedmiotem następnego aktu prawnego - zatwierdzonego w dniu 2 sierpnia $1861 \mathrm{r}$. przez rosyjskiego imperatora stanowiska Głównego Komitetu do Spraw Włościan - było zniesienie podwójnego oczynszowania włościan, pracujących w niektórych majątkach ziemskich położonych w guberni mińskiej, i wprowadzenie zasad zamiany tej powinności na pańszczyznę wykonywaną na rzecz dworu ${ }^{44}$. Normy dopełniające przepisy wchodzące w skład aktów prawnych reformy włościańskiej ustanowiono także na mocy zatwierdzonej przez cesarza w dniu 10 września 1862 r. uchwały Rady Państwa (Gosudarstwiennyj sowiet $)^{45}$ oraz afirmowanych również przez panującego $\mathrm{w}$ dniu 21 listopada 1862 r. zasad uzupełniających status prawnych chłopów czasowo-zobowiązanych. Właściwość miejscowa objęta tymi dwoma źródłami prawa dotyczyła guberni północno-zachodnich, z wyjątkiem guberni mohylewskiej i części powiatów (dyneburski, drysieński, lucyński i rzeżycki) guberni witebskiej. Pierwsze z nich potwierdziło przede wszystkim istnienie obowiązku jak najszybszego spisywania listów nadawczych ${ }^{46}$. Drugie nawiązywało zaś do odpowiednich przepisów Ustawy miejscowej o terytorialnym urządzeniu włościan osiadlych na obywatelskich ziemiach $w$ guberni: wileńskiej, grodzieńskiej, kowieńskiej, mińskiej i części witebskiej, na mocy których miały zostać powołane w każdym powiecie komisje weryfikacyjne ${ }^{47}$. W myśl zatwierdzonych komentarzy i wyjaśnień, postanowiono nie powoływać takiej instytucji, ze względu na małą liczbę włościan (3000 dusz), w powiecie sokólskim guberni grodzieńskiej. Wykonywanie obowiązków wynikających z podpisanych listów nadawczych na tym obszarze miała kontrolować komisja wersyfikacyjna zlokalizowana w jednym z sąsiednich powiatów. Zezwolono przy tym na uprawnienie tworzenie jednej komisji weryfikacyjnej działającej na terenie kilku powiatów, jednak-

${ }^{43}$ Ibidem, s. 88; zob. też: O pojasnienii punkta 4-go prawit dlia sostawlenija urocznych polożenij w guberniach wilenskoj, grodnienskoj, kowienskoj, misnkoj i czasti witebskoj, $11 \mathrm{~V}$ 1861, Potnoje sobranije zakonow Rossijskoj impierii, t. XXXVI, Sankt-Peterburg 1861, s. 742-743; Ustawa miejscowa o terytorialnym urządzeniu włościan osiadtych na obywatelskich ziemiach $w$ guberniach: wileńskiej, grodzieńskiej, kowieńskiej, mińskiej i części witebskiej, „Kurier Wileński” 4 IV 1861 (Wilno), nr 27, s. 249.

${ }^{44}$ I. Nikotin, op. cit., s. 91-92.

${ }^{45}$ Szerzej na temat Rady Państwa w Imperium Rosyjskim zob. D. Szpoper, Rada Państwa (1810-1917). Od subsydiarnego organu władzy rosyjskich imperatorów do izby wyższej parlamen$t u$, ,Opolskie Studia Administracyjno-Prawne” (2016), nr 2, s. 1-114.

${ }^{46}$ Ibidem, s. 92.

47 D. Szpoper, Pomiędzy caratem a snem o Rzeczypospolitej..., s. 239-240. 
że po uzyskaniu zgody stosownych władz gubernialnych oraz ministra spraw wewnętrznych ${ }^{48}$.

Szlachta litewska i białoruska zainteresowana była każdą zmianą wprowadzoną w sferze stosunków panujących na tamtejszej wsi. Gubernię wileńską, grodzieńską, mińską, mohylewską i witebską do wybuchu powstania styczniowego zamieszkiwało 9261 właścicieli ziemskich ,,polskiego pochodzenia”. Ta liczba stanowiła olbrzymią większość wszystkich osób należących do stanu szlacheckiego. Do momentu wprowadzenia reformy włościańskiej w lutym 1861 r. w majątkach należących do tej grupy pracowało 1131669 chłopów, co stanowiło $77 \%$ wszystkich znajdujących się tam włościan. Dodać należy, iż do tej grupy ziemian należało przeszło $90 \%$ prywatnej własności ziemskiej ${ }^{49}$.

W okresie datowanym pomiędzy momentem wprowadzenia reformy włościańskiej w guberniach zachodnich Cesarstwa Rosyjskiego a pierwszymi miesiącami po objęciu stanowiska generał-gubernatora wileńskiego, Michaił Murawjow dyskutował z zasiadającym z nim wspólnie w Komitecie do Spraw Reformy Chłopskiej Piotrem Wałujewem (pełniącym od listopada 1861 r. stanowisko ministra spraw wewnętrznych) ${ }^{50}$. Tematem przeprowadzanych przez nich rozmów była kwestia chłopska. Michaił Murawjow, zwracając się do Piotra Wałujewa, zdiagnozował czynniki mogące zagrozić realizacji celów stawianych przed ustawodawstwem włościańskim. Pisał w związku z tym: „W sprawie chłopskiej myślę, że główny problem [znajduje się - M.T.] w wycenach, bez których nic nie można zrobić $[\ldots]$ nigdy nie ustanowicie prawidłowych stosunków ziemskich i powinności chłopskich wobec posiadaczy i władz, dopóki nie będzie jasności co do wyceny chociażby przybliżonej, [...] ziem zagrodowych i ornych, udostępnionych gromadom [wiejskim - M.T.]" ${ }^{\prime 51}$. Nie dowierzając jakby w samoczynną moc aktów prawnych wchodzących w skład ustawodawstwa włościańskiego z 19 lutego 1861 r., stwierdzał dalej: „Można pisać ustawy, lecz bez spełnienia powyższego nie można wypełnić [postanowień reformy - M.T.]. Myślę, że o tym szybko się przekonacie, a także o tym, że do tego wszystkiego trzeba czasu i prawidłowego

${ }^{48}$ I. Nikotin, op. cit., s. 92; zob. też: Mnienije Gosudarstwiennago Sowieta, wysoczajsze utwierżdiennoje 21 nojabrja 1862 goda, objawlennoje Senatu, ministrom wnutriennych diel 27-go togo że nojabrja, 21 XI 1862, Polnoje sobranije zakonow Rossijskoj impierii, t. XXXVII, Sankt-Peterburg 1862, s. 350.

${ }^{49}$ S. Sambuk, Politika carizma w Bielorussii wo wtoroj połowinie XIX wieka, Mińsk 1980, S. 15.

${ }^{50}$ E. Fiedosowa, Graf M. N. Murawiew-Wilenskij (1796-1866): Żizn na stużbie impierii, Moskwa 2015, s. 121.

${ }^{51}$ Cyt. za: Lietuvos Valstybès Istorijos Archyvas, Wilno (LVIA), sygn. F. 439, ap. 1, b. 29 , mszp., M. Murawjow, List do P. Wałujewa, dat. [Sankt-Peterburg 1861 r.]. Kolekcja archiwum i muzeum hrabiego Michaiła Murawjowa, k. 2. 
urządzenia wewnętrznego i kierowania [...]"52. Dodatkowo Michaił Murawjow określał się jako zwolennik instytucji powoływanych właśnie na urzędy pośredników pojednawczych ${ }^{53}$. Ponadto uważał także, iż konieczne byłoby przeprowadzenie finalnie wykupu ziemi przez włościan oraz zainicjowanie akcji udzielania kredytów na ten cel przez władze państwowe. W ślad za tym proponował stworzenie odpowiedniego funduszu. Zaznaczał przy tym, iż poważnym problemem przy realizacji reformy stosunków wiejskich okazać się może sporządzanie listów nadawczych, albowiem jak przypuszczał wielu włościan będzie sprzeciwiało się temu rozwiązaniu ${ }^{54}$.

Ludność chłopska jeszcze przed wybuchem powstania styczniowego w Kraju Północno-Zachodnim (Siewiero-zapadnyj kraj) wielokrotnie wymieniana była przez przedstawicieli petersburskich kręgów politycznych, jako grupa mogąca się przysłużyć do osłabienia pozycji ekonomicznej litewsko-białoruskiej szlachty. O tego typu koncepcjach dyskutowano w październiku 1862 r. w ministerstwie spraw wewnętrznych. Na podstawie współpracy z Komitetem Zachodnim obradującym w Sankt Petersburgu ugruntowywały się opinie związane z sytuacją społeczno-polityczną w zachodnich prowincjach Imperium. Podkreślano wówczas, iż brak wystarczających środków finansowych wykluczał natychmiastowe rozwiązanie ,problemu zachodniego". Diagnozując istniejący tam stan rosyjskich interesów, potwierdzano także słuszność przyjętych politycznie założeń, sprowadzających się do stwierdzenia, iż: ,Jeśli polski element zasiedla kraj, co jest bezsporne, przy tym nie może być z niego wydalony [...] to wynika z tego, że rozwiązania władzy mogą być skierowane na to, aby osłabić ten element i pogodzić go w jego nierozerwalnym związku z Rosją [...] Oni sami wyprzedają tego kto im się ukłoni”"55. Pełniący urząd generał-gubernatora w latach 1856-1863 Władimir Nazimow uważał, iż do określonego w ten sposób zarysu programu politycznego, warto włączyć następujące działania: „,...] tam gdzie to jest możliwe, należy uprzedzać przyrost tych sił [...] wykorzystać siły sprzyjające [...] należy stosować kary w tych przypadkach gdzie jest to nieodzowne; należy razić materialne korzyści poszczególnych osób, a także całych stanów, jeśli te osoby i stany porywają się do walki z władzą, należy nadać rozporządzeniom większą siłę i jed-

${ }^{52}$ Cyt. za: ibidem, k. 2-3.

${ }^{53}$ LVIA, sygn. F. 439, ap. 1, b. 29, mszp., M. Murawjow, List do P. Wałujewa, dat. Syrec 5 VI 1861 r. Kolekcja archiwum i muzeum hrabiego Michaiła Murawjowa, k. 6.

${ }^{54}$ LVIA, sygn. F. 439, ap. 1, b. 29, mszp., M. Murawjow, List do P. Wałujewa, dat. Karlsbad 27 IV 1862 r. Kolekcja archiwum i muzeum hrabiego Michaiła Murawjowa, k. 9.

${ }_{55}$ Cyt. za: LVIA, sygn. F. 439, ap. 1, b. 27, mszp., Uzupetnienie, do raportu dotyczacego sytuacji w Kraju Zachodnim sporzadzonego przez ministerstwo spraw wewnętrznych na potrzeby obrad Komitetu Zachodniego, przedstawione przez generat-gubernatora wileńskiego Władimira Nazimowa, [Wilno] 18 XII 1862 r. Kolekcja archiwum i muzeum hrabiego Michaiła Murawjowa, k. 10. 
ność”. Wymienił on także metody walki z ,nieprzyjaznymi nurtami”. Postulował zatem: wzmocnienie nadzoru nad granicami Cesarstwa Rosyjskiego; zmiany granic administracyjnych niektórych powiatów; natychmiastowe przekazywanie dotacji publicznych na rzecz Cerkwi prawosławnej; wezwanie do Sankt Petersburga wszystkich marszałków szlachty i hierarchów Kościoła rzymskokatolickiego ,,[...] w celu wyjaśnienia im czego oczekuje władza"; wzmocnienie kontroli wykonywanej przez gubernatorów wobec organów sądownictwa karnego; rozważenie możliwości wprowadzenia stanu wojennego; czy też kierowania wojska w miejsca manifestacji politycznych. Podobnie jak władze centralne, podkreślił on rolę ludności włościańskiej, która mogła stać się instrumentem dla realizacji przyjętych założeń politycznych. Zaproponował przy tym potrzebę wprowadzenia działających na niekorzyść właścicieli ziemskich instytucji prawnych obowiązujących w trakcie obowiązkowego wykupu nadziałów gruntu przez chłopów, a także ,podtrzymywanie, ostrożną ręką, wzajemnej niechęci chłopów i ziemian, czy też ,szybkie utworzenie szkół wiejskich na podstawach zabezpieczających nie tylko podtrzymanie, ale rozprzestrzenianie rosyjskiej narodowości w kraju" ${ }^{56}$.

Ten sam przedstawiciel rosyjskiego aparatu administracyjnego spostrzegł także inne zagrożenia występujące we wsiach położonych w Kraju Północno-Zachodnim Cesarstwa Rosyjskiego po wejściu w życie reformy 1861 r. Uważał, iż w guberniach pozostających pod jego zarządem panowały specyficzne uwarunkowania prawno-społeczne. Ziemie te bowiem de iure objęte były imperium cesarza, zaś de facto ludność wiejska podlegała władzy „miejscowego polskiego ziemiaństwa” w myśl zasad, które zdołały przetrwać upadek Rzeczypospolitej Obojga Narodów ${ }^{57}$.

Rosyjski dygnitarz zdiagnozował również niepokojące jego zdaniem zjawisko zamieszkiwania ziem litewsko-białoruskich przez niewielką liczbę przedstawicieli szlachty pochodzącej z guberni wewnętrznych Rosji. Stanowili oni tylko dwa procent wszystkich osób należących do tego stanu na obszarze tych ziem. Z tego powodu powziął on myśl o konieczności zasiedlania północno-zachodnich prowincji rosyjskimi osadnikami, którzy na drodze nadania cesarskiego ${ }^{58}$ lub sprzedaży majątków państwowych mieli uzyskać prawo własności dóbr ziemskich. W ślad za tymi postanowieniami, Władimir Nazimow, wiosną 1860 r., wyjednu-

\footnotetext{
${ }^{56}$ Ibidem, k. 10v-11v.

57 A. Pawłow, Władimir Iwanowicz Nazimow gienierał-gubiernator Siewiero zapadnogo kraja, gienerat-adiutant, Sankt-Peterburg 1885, s. 40-41.

${ }^{58}$ Nadanie (pożalowanije) ziemi normy t. X Zbioru Praw Cesarstwa Rosyjskiego (art. 934966) zaliczały do jednego z tak zwanych darmowych sposobów nabywania prawa własności. Jedną z przesłanek nadawania gruntów państwowych było odznaczenie się w służbie publicznej; zob. Swod zakonow Rossijskoj impierii. Powielenijem gosudara impieratora Nikołaja pierwago sostawlennyj, Sankt-Peterburg 1857, t. X, s. 182-190.
} 
jąc dla swojego pomysłu wstępną akceptację Aleksandra II, przedstawił notatkę ogłaszającą potrzebę wzmocnienia położenia ludności rosyjskiej oraz stworzenia zasad, na podstawie których miała ona otrzymywać nieruchomości gruntowe do gospodarowania. Generał-gubernator zaproponował, aby w tej mierze uwzględniane były zasługi poniesione na rzecz państwa. W przypadku zaś sprzedaży nieruchomości stanowiących własność skarbu państwa, decydującym czynnikiem pozostawać miała wola osiedlenia się „ludności rosyjskiej” na zachodnich krańcach imperium Romanowów ${ }^{59}$. Nie bez znaczenia dla zainicjowanego w ten sposób programu wzmacniania w Kraju Północno-Zachodnim prawno-politycznego statusu poddanych ,rosyjskiego pochodzenia”, była aprobata, wykazywana wielokrotnie wobec działań władz rządowych w Wilnie, przez prawosławnego metropolitę Józefa Siemaszkę $e^{60}$. Jego pozycja, pomimo iż doprowadził do przymusowego włączenia unitów w struktury Cerkwi prawosławnej ${ }^{61}$, nie była jednak na tyle silna, aby dokonać erygowania prawosławnej akademii duchownej. Inicjatywa ta napotkała na sprzeciw administracji rosyjskiej argumentowany brakiem zaufania, nawet do prawosławnej części Białorusinów ${ }^{62}$.

Michaił Murawjow, po objęciu w warunkach trwającego powstania w dniu 1 kwietnia 1863 r. funkcji generał-gubernatora wileńskiego, mając silne przekonanie o potrzebie spacyfikowania zbuntowanych guberni przystąpił do ogólnego naszkicowania planu swych politycznych zamierzeń. Opowiadał się on za wprowadzeniem ,„...] normalnego porządku, potrzebnej wojskowej dyktatury i urządzenia tych guberni na podstawach, które przy nadzorowaniu warunków, zabezpieczających ich przyszły dobrobyt, przeciwdziałałyby próbie oderwania od Rosji jej dawnej własności”. Sposobami zrealizowania scharakteryzowanych w ten sposób zamiarów, było: ,,[...] zwrócenie guberni zachodnich narodowości rosyjskiej i przywiązanie do siebie mieszkańców wsi obcych polskim dążeniom"63.

Wileński generał-gubernator dostrzegał także konieczność wydawania rozporządzeń i aktów administracyjnych, które z jednej strony torowały drogę programowi usuwania z kręgu posiadaczy ziemskich ,,wrogiego Rosji polskiego elementu", z drugiej zaś wprowadzały rozwiązania sprzyjające włościanom w uniezależ-

59 A. Pawłow, op. cit., s. 54.

${ }^{60}$ Ibidem, s. 56.

${ }^{61}$ D. Szpoper, Kościół katolicki w Cesarstwie Rosyjskim przed 1863 r. Przyczynek do porozbiorowych dziejów ziem byłego Wielkiego Księstwa Litewskiego, [w:] Cuius regio, eius religio? Zjazd Historyków Państwa i Prawa Lublin, 20-23 IX 2006 r., red. G. Górski, L. Ćwikła, M. Lipska, Lublin 2006, s. 253.

${ }_{62}$ O. Łatyszonek, A. Mironowicz, Historia Białorusi od połowy XVIII do końca XX wieku, Białystok [2002], s. 101.

${ }^{63}$ Cyt. za: LVIA, sygn. F. 439, ap. 1, b. 27, mszp., Zapiska ob ustrojstwie zapadnych gubiernii posle wostanija $1863 \mathrm{~g}$., Wilno [1863 r.]. Kolekcja muzeum i archiwum hrabiego Michaiła Murawjowa, k. 1. 
nieniu się od wpływu polskiej szlachty. Michaił Murawjow uznał, iż urzędnicy podległej mu kancelarii generał-gubernatorstwa, powinni podjąć działania nakierowane na wzbudzenie zaufania mieszkańców wsi, co z kolei miało skutkować tym, iż ludność włościańska pozostawałaby wdzięczna i posłuszna miejscowym władzom rosyjskim. Natomiast w miejsce ,,polskiego” ziemiaństwa miał pojawić się „element czysto rosyjski lub niemiecki”64. Michaił Murawjow przewidywał, iż walka idąca w tych dwóch kierunkach nie będzie procesem przebiegającym bezproblemowo. Sukces tego planu uzależniał od „zrujnowania ekonomicznego” miejscowej szlachty, jednakże nie mogło to oznaczać w żadnym wypadku zahamowania rozwoju ekonomicznego Kraju Północno-Zachodniego ${ }^{65}$.

Z popieranego przez Michaiła Murawjowa katalogu działań wyłaniał się obraz metod mających służyć zmniejszaniu dochodów właścicieli ziemskich, co finalnie miało skutkować powstaniem zadłużenia ich dóbr, a w konsekwencji doprowadziłoby do przymusowej wyprzedaży tych majątków. Przy realizacji tego celu zakładał: obowiązkowy wykup chłopskiej ziemi; wprowadzenie podatku w wysokości dziesięciu procent od dochodu; egzekwowanie od ziemian wszystkich należnych na rzecz włościan świadczeń; rezygnacja miejscowej policji z pomocy w odzyskiwaniu przez szlachtę od chłopów należnego im czynszu (obroku); dokonywanie wycinek lasów na gruntach państwowych, z jednoczesnym bezpłatnym udostępnieniem chłopom drewna pochodzącego ze ścinki ${ }^{66}$.

Generał-gubernator wileński zauważał także potencjalne negatywne konsekwencje zamierzonego programu politycznego. Uważał, iż pauperyzacja litewsko-białoruskiej szlachty, ukształtowanie się swoistego ,,proletariatu szlacheckiego" może doprowadzić do radykalizacji nastrojów i przeniesienia się buntowniczych zachowań na masy chłopskie. Dodatkowo podkreślał, iż nie można było popełnić błędu, który miałby polegać na pozostawieniu bez pomocy, dotychczas przebywających na terytorium guberni północno-zachodnich rosyjskich właścicieli ziemskich (zasłużonych oficerów, urzędników cywilnych). Otoczenie ich opieką i wprowadzenie instrumentów prawno-ekonomicznych, wspierających byt tego środowiska na niwie materialnej i gospodarczej, miało stanowić czytelny sygnał dla innych potencjalnych osadników, którzy przybywających na ziemie litewsko-białoruskie z guberni wewnętrznych Rosji. Ilustrował to rozwiązaniami przyjętymi w Wielkim Księstwie Poznańskim. Murawjow pisał: „Pruskie władze [...] postępują inaczej. Tam też było powstanie, w którym uczestniczyła szlachta, ale władze nie tylko nie rozprzestrzeniały na niemieckich ziemian rozwiązań, mo-

\footnotetext{
64 Ibidem, k. 1.

65 Ibidem, k. 1v; zob. też: H. Korwin-Milewski, Siedemdziesiąt lat wspomnień (1855-1925), Warszawa 1993, s. 46.

66 Ibidem, k. 2.
} 
gących im przynieść straty w majątku, a przeciwnie wszelkimi środkami sprzyjały im przy nabywaniu tam majątków i teraz widzimy ponad połowę tych ostatnich w rękach Niemców" "67.

Kontynuując te rozwiązania, podkreślał wagę innego problemu, który mógł zahamować napływ rosyjskich osadników do Kraju Północno-Zachodniego. Było to występujące już wówczas zadłużenie nieruchomości ziemskich. Podkreślał, że ,$[\ldots]$ jak w całej Rosji, tak i w guberniach zachodnich dwie trzecie wszystkich majątków zastawionych jest w instytucjach kredytowych". Uważał, iż władze państwowe powinny uregulować ten stan rzeczy w taki sposób, aby móc zainteresować potencjalnych rosyjskich nabywców. $Z$ drugiej strony należało podjąć kroki, które wykluczyłyby możliwość spekulacji oddłużonymi gruntami. W tym kontekście Michaił Murawjow przestrzegał przed działaniami ludności żydowskiej ${ }^{68}$.

Generał-gubernator wileński, definiując rolę włościan w przygotowywanym przez niego planie politycznym, uważał, iż po zniwelowaniu wpływu „wrogiego polskiego elementu”, ta grupa społeczna będzie stanowiła „,mocne oparcie dla władz”. Wykonywana przez niego w tym zakresie analiza ujawniła wszakże pewne wątpliwości, albowiem biorąc pod uwagę zaangażowanie chłopstwa w toczące się wówczas walki powstańcze, nie widział powodu do nadmiernego optymizmu. Wątpiąc w lojalność włościan z dóbr rządowych wobec aparatu administracyjnego, wysnuwał zarazem tezy dotyczące ludności pracującej na rzecz dworu szlacheckiego: „Władze szczodrze ich [chłopów państwowych - M.T.] nadzieliły ziemią i zamieniły pańszczyznę nieznacznym czynszem pieniężnym [...]. Fakt ten nie stanowi znaczącej gwarancji, że włościanie z nieruchomości prywatnych, kiedy znajdą się w takiej lub lepszej sytuacji, jak obecnie państwowi, nie okażą się takimi samymi, jak ci ostatni”“99.

Michaił Murawjow przewidywał, iż dodatkowym efektem usamowolnienia włościan, będącym skutkiem reformy Aleksandra II z 1861 r., staną się przejawy zanarchizowania zachowań części tej grupy społecznej, a zatem należało w jego opinii spodziewać się wzrostu przestępczości - kradzieży i rabunków. Dodatkowo rosyjscy urzędnicy informowali go o występujących w warunkach trwającego powstania przypadkach plądrowania w guberniach litewsko-białoruskich siedzib lokalnej administracji ${ }^{70}$. Całokształt sytuacji skłaniał wileńskiego generał-gubernatora do dość pesymistycznych wniosków. Expressis verbis stwierdzał: „Przy takich nastrojach, samowola chłopów w zachodnich guberniach obecnie nie ma żadnych granic. Grabią lasy, bydło wypasają na pańskich łąkach lub wyganiają

\footnotetext{
${ }^{67}$ Cyt. za: ibidem, k. 2v.

${ }^{68}$ Cyt. za: ibidem, k. 3.

${ }^{69}$ Cyt. za: ibidem, k. 9.

70 D. Fajnhauz, 1863. Litwa i Białoruś, Warszawa 1999, s. 185.
} 
na zasiane pola i bez zakazów oddają się bezprawiu". W imię doraźnego interesu politycznego generał-gubernator wileński był w stanie chwilo tolerować takie postawy. Jednakże uważał, iż w długofalowym ujęciu, stanowiły one niebezpieczeństwo dla bytu państwa. Charakteryzując to zagadnienie, Murawjow konstatował: „Nastąpią w końcu czasy, kiedy będzie potrzeba położenia kresu tej sytuacji i wówczas trzeba będzie uciec się do stanowczości, już nie przeciwko Polakom, a wobec tych chłopów, w których władze zakładają znalezienie głównej, lepiej powiedzieć, jedynej podpory w przeciwdziałaniu wobec wrogiego polskiego elementu" 71 .

Większość poglądów wygłaszanych w początkowym okresie swoich rządów przez Michaiła Murawjowa nie uległa dezaktualizacji w kolejnych latach. Zgodnie z treścią sporządzonej - w marcu 1864 r. - instrukcji, chłopi powinni zostać otoczeni opieką władz miejscowych oraz podlegać wpływom odpowiednio uświadomionych pośredników pojednawczych. Tak ogólnie wyznaczone cele miały przyświecać działaniom podległych mu gubernatorów. Zdania te, realizowane w warunkach obowiązywania ustawodawstwa włościańskiego z 1861 r., powinny odciąć ludność chłopską od ,„przejawów bezprawnych żądań i szkodliwego wpływu polskiej propagandy". Michaił Murawjow postulował odzyskanie możliwości kształtowania postaw moralnych wśród włościan. Domagał się przy tym ustanowienia warunków sprzyjających upowszechnieniu się „,zasad rosyjskiej narodowości w duchu prawosławia i osłabiania przejawów obcych wpływów"72. Zagadnieniem umożliwiającym ocenę zbliżenia się części chłopów zamieszkujących gubernie północno-zachodnie z Cerkwią prawosławną była sprawa różnorodności wyznaniowej, występującej wśród włościan, zwłaszcza w guberniach litewskich. Tam olbrzymia większość z nich była wyznania rzymskokatolickiego. Z kolei, czynnik ten - zdaniem Murawjowa - decydował w wielu przypadkach o ciążeniu tej grupy ku miejscowej szlachcie ${ }^{73}$.

Generał-gubernator wileński w zarysach planów poświęconych procesom wpływania na etyczne postawy włościan ziem litewsko-białoruskich, opartych na kanwie „narodowości rosyjskiej”, wyraźnie akcentował na tym polu rolę Cerkwi prawosławnej i osobistą przywoływanego już arcybiskupa Józefa Siemaszki. Wileński metropolita jawił mu się w tym kontekście jako osoba skutecznie zabiegająca o, ,[...] uwolnienie włościan od wpływu i jarzma katolickich panów, którzy

${ }^{71}$ Cyt. za: LVIA, sygn. F. 439, ap. 1, b. 27, mszp., Zapiska ob ustrojstwie zapadnych gubiernii posle wostanija $1863 \mathrm{~g}$., Wilno [1863 r.] Kolekcja muzeum i archiwum hrabiego Michaiła Murawjowa, k. $11 \mathrm{v}-12$.

72 M. Murawjow, Gospodam naczalnikam gubernii Siewiero-zapadnogo kraja, 15 III 1864 g., [Wilno 1864], [b.p.].

${ }^{73}$ R. Jurkowski, Ziemiaństwo polskie Kresów Pótnocno-Wschodnich 1864-1904. Działalność społeczno-gospodarcza, Warszawa 2001, s. 98. 
nie pozwalali swoim poddanym swobodnie się przejąć religią prawosławną"74. Pozostając $\mathrm{w}$ tym przeświadczeniu, podkreślając jednocześnie własne zasługi na polu rzeczywistego uwolnienia od zawisłości poddańczej chłopów, stwierdził: „Powstanie r.[oku] 1863 uwieńczyło całą tę sprawę [wzmacniania „narodowości rosyjskiej” - M.T.], gdyż włościanie otrzymawszy wolność przez ukaz 3 marca (19 lutego 1861 r.[oku]), osiągnęli ją rzeczywiście dopiero w roku 1863, zostawszy zupełnie zabezpieczeni od jarzma i rabunku dawnych swych panów, uczuli całą ważność przyłączenia się swego do prawosławia i do narodowości rosyjskiej, i stali się trwałą podstawą przyszłego rozwoju elementu rosyjskiego, który musi być nieodłącznym od prawosławia"75.

Pomocne $\mathrm{w}$ promowaniu prorosyjskiego, a jednocześnie represyjnego, antypolskiego programu politycznego $\mathrm{w}$ guberniach północno-zachodnich miały okazać się szkoły ludowe (narodnyje ucziliszcza), które nadzorowane były przez, sprawującego w latach 1864-1868 funkcję kuratora Wileńskiego Okręgu Naukowego, Iwana Korniłowa ${ }^{76}$. Dobre relacje łączące go $\mathrm{z}$ generał-gubernatorem wileńskim zostały uwidocznione w liście z marca 1864 r., adresowanym łącznie do dwóch osób: redaktora „Moskiewskich Wiadomości” Michaiła Katkowa ${ }^{77}$ oraz związanego z tym samym czasopismem Pawła Leontiewa ${ }^{78}$. Iwan Korniłow podkreślił osiągnięcia i zasługi Michaiła Murawjowa, który w jego oczach był niezwykle skuteczny w realizacji swojej misji w guberniach północno-zachodnich, na których to ziemiach ,[...] nie ma rdzennego rosyjskiego społeczeństwa, gdzie jest tylko naród nieświadomy, biedny, uciskany i w niektórych miejscach uwiedziony i skażony wiekowym uciskiem przez polonizację i katolicyzm"79. Relacjonował on jednocześnie, iż wcześniejsze ustalenia poczynione $\mathrm{z}$ tamtejszym generał-gubernatorem i prawosławnym duchowieństwem. Zgodnie z nimi Michaił Murawjow zadeklarował, iż będzie wspierał projekt wybudowania czterystu szkół publicznych. Taka liczba miała w znaczący sposób zabezpieczyć plany po-

${ }^{74}$ Cyt. za: M. Murawjow, Pamiętniki Michała Mikołajewicza Murawjewa „Wieszatela” 18631865, Kraków 1902, s. 86.

75 Cyt. za: ibidem, s. 87.

76 L. Zasztowt, Kresy 1832-1864. Szkolnictwo na ziemiach litewskich i ruskich dawnej Rzeczypospolitej, Warszawa 1997, s. 79.

77 Należy dodać, iż Michaił Katkow zdecydowanie krytykował zryw powstańczy na zachodnich krańcach rosyjskiego Imperium w 1863 r., przypisując jego organizatorom tendencje separatystyczne; K. Sokołow, Rossijskaja intielligiencija XVIII - naczała XX ww.: kartina mira i powsiedniewnost, Sankt-Peterburg 2007, s. 265; zob. też: A. Andrusiewicz, Cywilizacja rosyjska, t. II, Warszawa 2005, s. 369.

78 Paweł Michajłowicz Leontiew, ,Niwa” 1 VI 1875 (Sankt-Pterburg), nr 22, s. 339.

${ }^{79}$ Cyt. za: Rossijskaja Nacjonalnaja Biblioteka, Sankt-Peterburg (RNB), sygn. F. 377, ap. 1, b. 360, rkps, I. Korniłow, List do Michaiła Katkowa i Pawła Leontiewa, dat. Wilno III 1864 r. [brak daty dziennej], Kolekcja Iwana Korniłowa, k. 3. 
lityczne władz rosyjskich w tej części Imperium Rosyjskiego. Wileński kurator podkreślał, że dotychczasowa sieć placówek oświatowych była niezadowalająca, a kadra nauczycielska charakteryzowała się jego zdaniem zbyt wysokim stopniem „spolonizowania"so.

Dodać należy, iż szkoły ludowe w guberniach zachodnich uzyskały podstawę prawną swego funkcjonowania na mocy najwyższego postanowienia rosyjskiego imperatora w dniu 18 stycznia 1862 r. Jeszcze w ostatnich dniach rządów generał-gubernatora wileńskiego Władimira Nazimowa - 23 marca 1863 r. - zostały ustalone także szczegółowe zasady działania tych wiejskich zakładów naukowych. Otwarcie pierwszych z nich odbyło się w tym samym roku. Z kolei, biorąc pod uwagę działania podejmowane przez Michaiła Murawjowa, należy zaznaczyć, iż w dniu 1 kwietnia 1864 r. doprowadził on do otwarcia trzystu osiemdziesięciu dziewięciu szkół elementarnych ${ }^{81}$.

W ślad za głównymi koncepcjami politycznymi nakierowanymi na potwierdzenie ,rosyjskiego charakteru Kraju Zachodniego” centralny, a także funkcjonujący na poziomie terytorialnym aparat administracyjny dążył do wydawania aktów prawnych umożliwiających wcielenie w życie koncepcji depolonizacji tych ziem. Wymiana poglądów pomiędzy Michaiłem Murawjowem a ministrem spraw wewnętrznych Piotrem Wałujewem w 1863 r. potwierdzała, iż włościanie stanowili „materialną siłę”, pozwalającą na wykorzystanie ich energii przeciw miejscowej szlachcie. Istotny był fakt, iż oparcie się na antagonizmach występujących pomiędzy tymi grupami uzasadniano nie tylko z socjalno-ekonomicznego punktu widzenia, lecz także przy uwzględnieniu czynników pochodzenia etnicznego ${ }^{82}$.

80 Ibidem, k. 4v.

81 Jednocześnie w wyniku toczących się na szczeblu centralnym prac - nadzorowanych przez ministra oświecenia publicznego Aleksandra Gołowina - związanych z powołaniem szkół ludowych w Rosji, w dniu 14 lipca 1864 r. imperator wydał ukaz określający status prawny tych placówek. $R a-$ tio legis przyświecające temu aktu prawnemu zakładało utworzenie instytucji oświatowych wzmacniających wśród uczniów - będących dziećmi włościan - poczucie wartości religijnych i moralnych. Moc obowiązująca ukazu nie została rozciągnięta wszakże na gubernie litewsko-białoruskie, gdyż jego normy miały być stosowane wyłącznie w petersburskim okręgu naukowym, z wyłączeniem guberni witebskiej i mohylewskiej, a także okręgach naukowych z siedzibą w Kazaniu, Charkowie i Odessie oraz w guberniach: czernichowskiej i połtawskiej, w których szkoły podlegały nadzorowi kijowskiego kuratora naukowego; zob. S. Tatiszczew, Impierator Aleksander II. Jego żizn i carstwowanije, Moskwa 2006, s. 622-623.

82 P. Briancew, Istorija litowskago gosudarstwa s driewniejszich wriemien, Wilno 1889, s. 653; zob. też: M. Dołbiłow, Stratiegija diepołonizacij. Polityka «russkogo dieła» w zapadnych gubernijach w 1863-1868 gg., gława 7, razdieł 1, [w:] Zapadnyje okrainy Rossiijskoj impierii, red. M. Miller, M. Dołbiłow, Moskwa 2007, s. 211; M. Dołbiłow, Problema russkoj idienticznosti w Zapadnom kraje, gława 7, razdieł 3, [w:] Zapadnyje okrainy Rossiijskoj impierii, red. M. Miller, M. Dołbiłow, Moskwa 2007, s. 228; W. Zajączkowski, Rosja i narody. Ósmy kontynent. Szkic dziejów Eurazji, [Warszawa] 2015, s. 134. 
Konsekwencją przyjęcia takich założeń stał się kreowany przez władze rosyjskie, także na gruncie polityki agrarnej, obraz utożsamiający włościan zamieszkujących gubernię mińską, grodzieńską i przeważającą część powiatów guberni wileńskiej z Białorusinami. Za tym z kolei szedł często podkreślany pogląd, iż „Białoruś to także Rosja”, tak jak żyjąca na tych ziemiach populacja była tym „rosyjskim narodem”, który zamieszkiwał także „,wielkorosyjskie” terytoria. Czyniono tylko pewne zastrzeżenia, opierające się na występujących tam różnicach lingwistycznych. Nawiązując do tej kwestii, zauważano, że miejscowa ludność chłopska operowała językiem „ruskim”, jednakże „nieco zmienionym, w skutek długotrwałej zależności Białorusi od Polski" ${ }^{83}$. Michaił Murawjow, doszukując się sukcesów w prowadzonej przez siebie polityce ,utrwalania sprawy rosyjskiej” w Kraju Północno-Zachodnim, zwracał uwagę, iż powinnością rosyjskiego rządu jest wzmacnianie rozwoju języka rosyjskiego i prawosławia na ziemiach litewsko-białoruskich, na których ,naród polski nigdy nie istniał”. Murawjow, uzupełniając ten stricte polityczny pogląd przekonaniami na temat roli żywiołu włościańskiego stwierdził: „Lud prosty także zaczął się przyczyniać do budowy cerkwi prawosławnych [...] Słowem, sprawa rosyjska i prawosławie odżyły w kraju. Wszędzie rozpowszechniło się przekonanie o byłej rosyjskiej narodowości w tak nazywanym przez Polaków kraju zabranym"»4.

W dniu 1 marca 1863 r. - a zatem w ostatnich tygodniach pobytu w Wilnie Władimira Nazimowa jako generał-gubernatora - wydany został ukaz o obowiązkowym wykupie nadziałów ziemi, które użytkowane były przez chłopów czasowo zobowiązanych w następujących guberniach: wileńskiej, grodzieńskiej, kowieńskiej, mińskiej oraz w niektórych powiatach guberni witebskiej (dyneburskim, drysieńskim, lucyńskim i rzeżyckim $)^{85}$. W wyniku wejścia w życie tych przepisów, włościanie zostali zaliczeni do grupy chłopów-właścicieli, dla których obniżano sumę wykupu nadziału o dwadzieścia procent ${ }^{86}$. Relacja czasowego zobowiązania miała być utrzymana do dnia 1 maja 1863 r. Od tej daty chłopi zostali zaliczeni do grona właścicieli gruntów. Do czasu zaś podpisania aktu wykupu byli zobowiązani uiszczać czynsz we właściwych Izbach Dóbr Państwowych ${ }^{87}$. Korzystne dla włościan

${ }^{83}$ M. Kojałowicz, Wiernopoddanniczestwo Poljakow Zapadnom Rossiji, [w:] Sbornik statiej razjasnjajuszczich polskoje dielo po otnoszeniju $k$ Zapadnoj Rossiji, red. S. Szołkowicz, Wilno 1885, s. 372; zob. też: A. Tichomirow, ,,Wiestnik Zapadnoj Rossii”: oświata w kontekście idei ,zachodniorusizmu” 1862-1866, „Rozprawy z Dziejów Oświaty” (2006), nr 45, s. 283.

${ }^{84}$ Cyt. za: M. Murawjow, Pamiętniki Michała Mikołajewicza..., s. 112.

${ }^{85}$ Ukaz z dnia 1 marca 1863 r., znosząc status czasowego zobowiązania, rozciągnął w pełni treść reformy włościańskiej z 1861 r. na grupę chłopów użytkujących dotychczas nadział gruntu; zob.; I. Nikotin, op, cit., s. 93; zob. też: I. Isajew, Istorija gosudarstwa i prawa Rossiji..., s. 431; S. Łaniec, Białoruś w drugiej połowie XIX stulecia, Olsztyn 1997, s. 119.

${ }^{86}$ M. Dołbiłow, Problema russkoj idienticznosti..., s. 229.

${ }^{87}$ P. Zajonczkowskij, Otmienia kriepostnogo prawa w Rossiji, Moskwa 1968, s. 215. 
normy ukazu mogły choć w pewnym stopniu złagodzić występujący problem związany z chłopskimi skargami, kierowanymi do władz rosyjskich w sprawie pomniejszania rozmiarów przeznaczonych dla nich nadziałów ziemskich. Niemniej przez cały okres rządów Michaiła Murawjowa do podległej mu kancelarii napływały informacje świadczące o tym zjawisku. W piśmie skierowanym w marcu $1865 \mathrm{r}$. do gubernatora kowieńskiego Nikołaja Michaiłowicza Murawjowa ${ }^{88}$, Nazimow zaproponował, aby pośrednicy pojednawczy i członkowie komisji weryfikacyjnych zwrócili uwagę na ten fakt, a także odpowiednio pouczyli miejscowych włościan oraz sądy o ratio legis przepisów ustaw miejscowych wchodzących w pakiet aktów normatywnych objętych przepisami reformy z 19 lutego $1861 \mathrm{r} \cdot{ }^{89}$ We wcześniej zaś wyrażanych opiniach zaznaczał on, iż kwestia pomniejszania areału gruntów nadziałowych wymagała pilnej interwencji z uwagi na potrzebę utrzymania na terenie podległych mu prowincji spokoju publicznego, gdyż ,[...] chłopi nie mający stałego zamieszkania i nadziałowej ziemi często fałszywymi obietnicami przyciągani byli do uczestnictwa w zamieszkach"90.

W związku z ukazem z dnia 1 marca 1863 r., wydano w dniu 9 kwietnia tego samego roku zatwierdzone przez rosyjskiego monarchę zasady, skonstruowane przez Główny Komitet do Spraw Włościańskich, powołujące komisje weryfikacyjne odpowiedzialne za nadzorowanie czynności prowadzących do wykupu nadziałów ziemi przez włościan w guberniach: wileńskiej, grodzieńskiej, kowieńskiej, mińskiej oraz w czterech powiatach (dyneburskim, drysieńskim, lucyńskim i rzeżyckim) guberni witebskiej. Normy zawarte w tym akcie prawnym ustanawiały obowiązek zakończenia działalności komisji weryfikacyjnych w ciągu dwóch lat ${ }^{91}$.

${ }^{88}$ Nikołaj Michaiłowicz Murawjow nie utracił stanowiska gubernatora kowieńskiego z chwilą objęcia w 1865 r. urzędu przez kolejnego generał-gubernatora wileńskiego Konstantego von Kauffmana; zob. Pamiatnaja kniżka kowienskoj gubiernii na 1865 goda, Kowno 1865, s. 10-11; zob. też: Pamiatnaja kniżka kowienskoj gubiernii na 1866 god, Kowno 1866, s. 8.

${ }^{89}$ LVIA, sygn. F. 439, ap. 1., b. 15, mszp., Priedłożenija G. wilenskogo, kowienskogo, grodnienskogo i minskogo gienierat-gubernatora i gławnogo naczalnika witebskoj i mogilewskoj gubernij ot 10 marta 186[5] goda, Wilno 10 III 186[5] r., k. 59.

${ }^{90}$ Cyt. za: LVIA, sygn. F. 439, ap. 1., b. 20, mszp., Pismo Michaiła Murawjowa do gubernatora wileńskiego, dat. Wilno 17 VIII 1863 r. Kolekcja muzeum i archiwum hrabiego Michaiła Murawjowa, k. 60 .

${ }^{91}$ Instytucje te składały się z dwóch przedstawicieli władz (mianowanych odpowiednio przez ministra spraw wewnętrznych i ministra finansów) oraz pośrednika pojednawczego. W aneksach do zasad działalności komisji weryfikacyjnych wydanych w dniu 9 kwietnia 1863 r. wprowadzono także oficjalny formularz aktu wykupu ziemi; zob. Wysoczajsze utwierżdiennyja prawiła 9 aprielja 1863 goda o sostaw i porjadkie diejstwij powierocznych kommisij w gubierniach: wilenskoj, grodniejskoj, kowienskoj, minskoj i w ujezdach dinaburskom, drizenskom, liucienskom i rieżickom witiebskoj gubierni, [w:] Sbornik prawitielstwiennych rasporiażenij po ustrojstwu byta kriestian-sobstwiennikow w Siewiero-zapadnom kraje, Wilno 1864, s. 9-10 i 22. 
Ze sprawą uprawnienia chłopów do wykupu użytkowanej przez nich ziemi wiązał się - newralgiczny dla całego okresu - problem serwitutów (wypasu bydła, połowu ryb, wyrębu lasów) na gruntach dworskich ${ }^{92}$. Występowały one w przeszło połowie należących do ziemian nieruchomości zlokalizowanych w guberni mińskiej, grodzieńskiej i wileńskiej ${ }^{93}$. W tym czasie administracja rządowa Kraju Północno-Zachodniego stanęła przed koniecznością dokonania interpretacji przepisów opartych zarówno na ustawodawstwie włościańskim, jak i ukazie z dnia 1 marca 1863 r. o przymusowych aktach wykupu. Wątpliwość dotyczyła kwestii sukcesji uprawnień serwitutowych na mocy obowiązkowego aktu wykupu nadziału ziemskiego. W okresie rządów Michaiła Murawjowa przyjęto, iż sam fakt korzystania przez włościan w okresie zawisłości poddańczej z ustalanych - z reguły na zasadzie zwyczajowej - serwitutów, z pominięciem ukonstytuowania tych uprawnień w przymusowych aktach wykupu, skutkował istnieniem w dalszym ciągu obowiązków pomiędzy stronami stosunku serwitutowego ${ }^{94}$. Służebności, a także utrzymanie po reformie włościańskiej szachownic gruntów ornych były problemami wymagającymi pilnego rozwiązania. Jednakże, działania władz w prowincjach północno-zachodnich, podobnie jak w przypadku administracji rosyjskiej w Królestwie Polskim, nie przewidywały konstruktywnych rozwiązań idących w kierunku łagodzenia antagonizmów pojawiających się z tego powodu pomiędzy ziemianami i włościanami ${ }^{95}$.

Zgoła odmienne utrudnienia, spowalniające proces nabywania ziemi przez chłopów, wystąpiły w listopadzie $1863 \mathrm{r}$. w powiecie brzeskim w guberni grodzieńskiej. Sprawa dotyczyła sporządzania aktów wykupu nieruchomości położonych nad Bugiem, gdzie w niektórych majątkach ziemskich część chłopskiego nadziału znajdowała się na terytorium Królestwa Polskiego. Przyjęto wówczas rozwiązanie zaproponowane przez gubernatora grodzieńskiego, który uznał, iż

92 Serwitut (służebność) stanowił rodzaj prawa rzeczowego uprawniającego osobę (podmiot służebności) do określonego w granicach prawa korzystania z cudzej rzeczy. Pomiędzy właścicielem nieruchomości, na której ustanowiono serwitut a podmiotem służebności nawiązywał się stosunek prawny w celu zaspokojenia interesu prywatnego; zob. E. Waśkowskij, Uczebnik grażdanskogo prawa. Wieszcznoje prawo, Sankt-Peterburg 1896, s. 83-84; zob. też: F. Bossowski, Prawo cywilne dzielnic polskich w zarysie. Część IV. Prawo cywilne ziem wschodnich obejmujacych województwa: Nowogrodzkie, Poleskie, Wołyńskie oraz powiaty: grodzieński, wołkowyski i białowieski województwa Białostockiego tudzież ziemię Wileńska, red. F. Zoll, Warszawa-Kraków [1922], s. 128.

${ }_{93}$ M. Kosman, Historia Białorusi, Wrocław 1979, s. 237.

94 Wykładania idąca w tym kierunku została zakwestionowana w 1883 r. na mocy postanowień Senatu Rządzącego w Sankt Petersburgu; zob. K. Abramowicz, O krestianskich serwitutach w gubernijach zapadnych, pribaltijskich i Carstwa Polskogo, S.[ankt]-Peterburg 1895, s. 27-28.

95 S. Lubicz. [S. Kozicki], Sprawa włościańska w Polsce porozbiorowej, Kraków 1909, s. 303. 
części działek znajdujących się w granicach Królestwa Polskiego powinny były zostać zamienione na grunty zlokalizowane na terenie podległej mu prowincji ${ }^{96}$.

Włościanie z obszaru generał-gubernatorstwa wileńskiego zwracali się z wnioskami także w sprawie poboru rekruta. W październiku 1864 r. Michaił Murawjow polecił gubernatorowi wileńskiemu, aby skargi na postanowienia gromad wiejskich przekazywano do rozpatrzenia do właściwych pośredników pojednawczych, którzy powinni przedłożyć je celem rozpoznania powiatowym zjazdom pośredników pojednawczych ${ }^{97}$. W grudniu tego samego roku wileński generał-gubernator na mocy wydanego przez niego okólnika postanowił zaś, iż wstępowanie do armii rosyjskiej chłopów może być w swych szczegółowych aspektach unormowane regulaminami uchwalanymi przez gromady wiejskie ${ }^{98}$.

W warunkach toczących się walk powstańczych Michaił Murawjow wydał także szereg innych zarządzeń i rozkazów regulujących status osobisty włościan, które co prawda nie stanowiły rozwinięcia norm prawnych ustanowionych reformą z 19 lutego 1861 r., niemniej akty te można było interpretować jako wyraźny przykład realizacji, dotychczas wyłącznie naszkicowanych w zaciszu rządowych gabinetów, potrzeb „pełnego przywrócenia” - państwowości rosyjskiej guberni zachodnich. Zamierzano czynić wedle przesłanek ,ruskiego pochodzenia”, a także wiary prawosławnej i języka rosyjskiego ${ }^{99}$. W programie politycznym władz generał-gubernatorstwa, cele polityczne, które w założeniach miały odwoływać się do postaw moralnych, łączono z priorytetową kwestią, jaką była sprawa jak najszybszego zwycięstwa nad powstańcami.

Spośród zarządzeń administracyjnych, których ustanowienie dawało szansę na realizację tych dwóch kluczowych zadań, wymienić można instrukcję z dnia 1 stycznia $1864 \mathrm{r}$. Zgodnie z jej treścią gubernatorzy mieli rozpowszechnić wśród miejscowej ludności (szlachty, także zagrodowej, niższych urzędników, kupców, mieszczan), wyłączając z tej grupy chłopów, informację o surowym karaniu prób jakiegokolwiek oddalania się z miejsca zamieszkania bez uzyskania zgody naczelnika powiatu (naczalnik ujezda). Zasady wyrażone w taki sposób należało stosować również wobec duchownych rzymskokatolickich. Ponadto, w tym samym dokumencie, generał-gubernator wileński postanowił, iż trzeba wyeliminować nauczanie języka

${ }^{96}$ Akty wykupnyje, [w:] Sbornik rasporjażenij grafa Michaiła Nikołajewicza Murawjowa po usmirieniju polskago miatjeża w Siewiero-zapadnych gubierniach 1863-1864, red. N. Cyłow, Wilno 1866 , s. $5-6$.

${ }^{97}$ LVIA, F. 439, ap. 1., b. 15, rkps, Pismo Michaiła Murawjowa do gubernatora wileńskiego, dat. Wilno 23 X 1864 r. Kolekcja muzeum i archiwum hrabiego Michaiła Murawjowa, k. 51.

${ }_{98}$ LVIA, sygn. F. 439, ap. 1., b. 15, mszp., Okólnik generał-gubernatora wileńskiego, dat. Wilno 11 XII 1864 r. Kolekcja muzeum i archiwum hrabiego Michaiła Murawjowa, k. 77.

99 S. Wiech, Epoka reakcji i pieriedyszki. Wileńscy generat-gubernatorzy wobec problemu polskiej własności ziemskiej w latach 1864-1884, „Kwartalnik Historyczny” (2008), nr 2, s. 58. 
polskiego wśród młodzieży chłopskiej uczęszczającej do szkół wiejskich. Z tego powodu na gubernatorów nałożono obowiązek nadzorowania przeprowadzanych przez zarządy szkół naborów kadry nauczycielskiej. Dodatkowo nakazano sprzyjać formom nauczania włościan przez duchownych prawosławnych realizujących właściwy program edukacyjny w placówkach publicznych. Wytyczne kierowane były zwłaszcza do dyrektorów, którzy powinni byli baczyć, aby prawosławne dzieci chłopskie nie uczono katechizmu Kościoła rzymskokatolickiego. Niezależnie od tych poleceń Michaił Murawjow stwierdził, iż podległe mu instytucje nie mogą zezwalać na korzystanie przez włościan z elementarzy i innych książek wydanych w języku polskim. Jeśli natomiast władze spostrzegą takie niebezpieczne zachowania, to odpowiedzialne za ten czyn osoby należało ukarać grzywną w wysokości od 200 do 600 rubli i objąć nadzorem policyjnym ${ }^{100}$. Natomiast odrębne zarządzenie zostało poświęcone nauczaniu języka polskiego lub religii przez księży, którzy za tego typu czyn podlegać mieli surowszej karze, nie mniejszej niż 300 rubli i aresztowaniu. Sankcje - grzywnę 100 rubli w połączeniu z odsunięciem od zajmowanych stanowisk w gromadach wiejskich - przewidziano także dla tych włościan, którzy uczestniczyli w nielegalnych formach nauczania i nie poinformowali o tym właściwych instytucji rządowych ${ }^{101}$. Władze gubernialne, w celu uzyskania kontroli nad relacjami łączącymi dwór i wieś, obciążono zadaniami monitorowania procesu powoływania na urzędy pośredników rozjemczych, którzy mieli być dodatkowo rekrutowani z grona osób „rosyjskiego pochodzenia”102.

Zgodnie z kolejną instrukcją wydaną w dniu 9 stycznia 1864 r., dokonywanie wyboru miejsca, w którym miały być lokalizowane wiejskie szkoły elementarne, nie mogło pozostać kwestią przypadku. Generał-gubernator wileński polecił, aby w planach budowy nowych budynków szkolnych uwzględniać położenie ich względem najbliższej cerkwi prawosławnej. Natomiast lokalizacja już istniejących placówek powinna zostać na nowo przemyślana pod kątem możliwości przeniesienia siedzib szkół w pobliże świątyń tego samego wyznania ${ }^{103}$.

Szkolnictwo ludowe miało zahamować - w opinii administracji generał-gubernatorstwa wileńskiego - rozwój tych form kształcenia, które zostało zapoczątkowane przez polskie ziemiaństwo po likwidacji poddaństwa. Podobny proces miał zachodzić w majątkach państwowych administrowanych przez izby dóbr państwowych, w których zatrudnieni urzędnicy „polskiego pochodzenia” nie

\footnotetext{
${ }^{100}$ Naczelnikam gubiernij 1 janwarja 1864 g., [w:] Sbornik rasporjażenij grafa Michaiła Nikotajewicza Murawjowa po usmirieniju..., s. 153-154.

${ }_{101}$ Obuczenije kriestian. Cirk.[ular] 1 janwarja 1864 g. [w:] Sbornik rasporjażenij grafa Michaiła Nikołajewicza Murawjowa po usmirieniju..., s. 227.

102 Naczelnikam gubiernij 1 janwarja 1864 g..., s. 154.

${ }_{103}$ Naczelnikam gubernij 9 janwarja 1864 g. [w:] Sbornik rasporjażenij grafa Michaiła Nikołajewicza Murawjowa po usmirieniju..., s. 155.
} 
przeciwstawiali się w zdecydowany sposób przejawom nauczania chłopów państwowych języka polskiego oraz katechizmu rzymskokatolickiego. Ta sama grupa nierosyjskich funkcjonariuszy rosyjskiej administracji, wspierana przez działalność katolickich księży, pisarzy gminnych, byłych absolwentów uniwersytetów i gimnazjów pozwalała na rozpowszechnianie się ,polskiej propagandy ze szkodą rdzennej ludności ruskiej do której przynależy prawie cała ludność wiejska"104.

Urzędnicy podlegli generał-gubernatorowi wileńskiemu mieli także czuwać nad budową nowych świątyń rzymskokatolickich, a także ich filii, czy też kaplic. Ich działania nadzorcze miały również obejmować decyzje podejmowane w sprawie tworzenia miejsc kultu religijnego. Jednym z przykładów takich postanowień, którego normy obowiązywały na obszarze guberni północno-zachodnich, uzależniających możliwość wznoszenia budynków sakralnych od zgody władz rządowych było zarządzenie administracyjne wydane w drugiej połowie 1863 r. w związku z przeglądem prac wszystkich guberni. Michaił Murawjow jak sam stwierdził - zamierzał w ten sposób przeciwdziałać osiedlaniu się „,polskiego elementu" i jego dominacji. Inspiracji dla jego wydania należy poszukiwać w informacjach o działalności rzymskokatolickiego duchowieństwa, które zgodnie $\mathrm{z}$ oficjalnymi doniesieniami ,,[...] w duchu rozpowszechnienia $\mathrm{w}$ narodzie polskiej religijnej i politycznej propagandy, stara się wnieść do wnętrza ruskiej ludności katolicyzm i polską propagandę - za pośrednictwem [...] miejsc boskiego kultu pod różną nazwą [...]”"105.

Popierana przez Michaiła Murawjowa polityka zasiedlania ziem północno-zachodnich krańców ludnością, która zgodnie z założeniami politycznymi miała przybyć z guberni centralnych Rosji, została wzmocniona aktami prawnymi, których normy pozwalały na stworzenie ulg i ułatwień dla ludności potencjalnie zainteresowanej nabywaniem nieruchomości prywatnych i skarbowych znajdujących się w Kraju Północno-Zachodnim. W założeniach rosyjskich władz osadnicy, którzy mieli dotrzeć na północno-zachodnie krańce Imperium, powinni nabywać pozostające $\mathrm{w}$ zarządzie izb dóbr państwowych grunty. Liczba nieruchomości przechodzących na własność bądź w stan administrowania przez skarb cesarstwa, w wyniku przeprowadzonych procesów konfiskowania bądź sekwestrowania, wzrosła znacząco po wybuchu powstania styczniowego. Podstawę prawną dla przeprowadzenia aktów konfiskujących majątki ziemskie należące do powstańców stanowiły normy zawarte w ustawie wojskowo-karnej z 1859 r. ${ }^{106}$ Natomiast

${ }^{104}$ Obuczenije kriestian. Cirk.[ular]..., s. 225.

${ }^{105}$ Cyt. za: Rewizija gubiernij, [w:] Sbornik rasporjażenij grafa Michaiła Nikołajewicza Murawjowa po usmirieniju..., s. 314.

106 O konfiskacii imuszczestw mjateżnikom i o nalożenii zaprieszczenija na imienija otcow, [w:] Sbornik prawitielstwiennych rasporjażenij po wodworieniju ruskich ziemlewladielcew w Siewiero-zapadnom kraje, Wilno 1870, s. 1. 
postępowanie sekwestrowe władze rosyjskie wykonywały na mocy dekretu Senatu Rządzącego z dnia 22 marca 1863 r., który został wydany na polecenie cesarza w sprawie mienia nieruchomego należącego do osób, które uczestniczyły w działaniach zbrojnych przeciwko państwu rosyjskiemu w graniczących z Królestwem Polskim guberniach ${ }^{107}$.

Kancelaria generał-gubernatora utrzymywała w sprawie zasiedlenia terenów guberni północno-zachodnich osadnikami „,rosyjskiego pochodzenia” stały kontakt z kierowanym przez Aleksandra Zielenoja ministerstwem dóbr państwowych. Michaił Murawjow informował wówczas, którym osobom widniejącym w ministerialnych rejestrach jako właściciele sekwestrowanych przez państwo majątków udowodniono ostatecznie udział w działaniach powstańczych. Biorąc pod uwagę doniesienia płynące $\mathrm{z}$ Wilna, minister Aleksandr Zielenoj wydał w dniu 25 lutego 1864 r. okólnik, w którym zarządził, iż wytypowane majątki prywatne, z powodu uczestnictwa niektórych ich właścicieli w powstaniu, a jednocześnie także z tytułu istniejącego na nich zadłużenia, zostały zaliczone do grupy nieruchomości oczekujących na zbycie w drodze licytacji. Dodawano, że niektóre ze wskazanych nieruchomości zostaną przeznaczone na potrzeby osadnictwa przez nieposiadających ziemi włościan - staroobrzędowców ${ }^{108}$. Sam zaś Michaił Murawjow, wspierając rozwój rosyjskiego osadnictwa, dostrzegał szczególną potrzebę przekazywania - starowiercom - majątków ziemskich w wieczystą dzierżawę ${ }^{109}$.

Istotne $\mathrm{w}$ kwestii planów osiedleńczych $\mathrm{w}$ guberniach zachodnich normy zostały również zatwierdzone przepisami ustanowionymi przez cesarza $\mathrm{w}$ dniu 5 marca 1864 r. Od tej daty wchodziły w życie reguły dotyczące udzielania ulg, świadczeń i pożyczek pieniężnych dla osób dobra ziemskie, tak prywatne, jak i pochodzące z puli rządowej. Utworzono także katalog osób, dla których stworzono preferencyjne warunki nabywania gruntów w dziewięciu guberniach zachodnich Cesarstwa Rosyjskiego. Ulgi zagwarantowano przedstawicielom wszystkich grup społecznych, „niepolskiego pochodzenia”, a zamieszkujących dotychczas gubernie centralne. Oprócz ludności polskiej z zakresu podmiotowego tego ukazu wyłączono również Żydów. Równie istotne postanowienie przewidywało, iż osoba „polskiego pochodzenia”, chcąca zbyć należącą do niej zadłużoną nieruchomość,

107 Ukaz Prawitielstwujuszczago Senata, ot 22 marta 1863 goda, [w:] Sbornik prawitielstwiennych rasporjażenij po wodworieniju ruskich ..., s. 4.

108 Otnoszenije Ministra Gosudarstwienncyh Imuszczestw G. wilenskomu, kowienskomu, grodnienskomu i minskomu gienierat-gubiernatoru i gławnomu naczelniku witebskoj i mogilewskoj gubiernij, ot 27 fiewrala 1864 g. [w:] Sbornik prawitielstwiennych rasporjażenij po wodworieniju ruskich..., s. 11; zob. też: Cirkuliarnoje priedłożenije ministra gosudarstwiennych imuszczestw gg. uprawliajuszczim pałatami gosudarstwiennych imuszczestw ot 25 fiewrala $1864 \mathrm{~g}$. [w:] Sbornik prawitielstwiennych rasporjażenij po wodworieniju ruskich ..., s. 11-12.

109 Z. Szybieka, Historia Białorusi 1795-2000, Lublin 2002, s. 124. 
miała obowiązek uzyskania zgody na sprzedaż tej części swojego majątku w drodze publicznej licytacji. Decyzję o jej przeprowadzeniu podejmował właściwy miejscowo generał-gubernator, obligatoryjnie uwzględniając normy wymagające zastosowania ulg i korzystnych świadczeń pieniężnych ${ }^{110}$. Publiczne licytacje odbywały się na podstawie przepisów tomu X Zbioru Praw Cesarstwa Rosyjskiego (Swod zakonow Rossijskoj impierii). Ich przedmiotem były zarówno określone przepisami prawa nieruchomości prywatne, jak i te należące do skarbu państwa. Prywatne dobra ziemskie mogły zatem zostać zbyte wyłącznie w przypadku, gdy podlegały one zastawowi w instytucjach kredytowych i równocześnie wystąpiła zwłoka w spłacaniu należności wynikających z zabezpieczonych na nich wierzytelnościach. Natomiast nieruchomości skarbowe podlegały sprzedaży w razie wystąpienia takiej potrzeby. Opinię w tej sprawie wydawało ministerstwo dóbr państwowych, a ostateczną decyzję podejmował osobiście imperator ${ }^{111}$.

Zadłużenie majątków prywatnych stanowiło poważny problem w gospodarce ziemskiej w guberniach litewsko-białoruskich. Zdaniem rosyjskich władz, potencjalni osadnicy przybywający z centralnej Rosji narażeni byli na skorzystanie z ofert sprzedaży gospodarstw położonych na nierentowanych gruntach. Kancelaria generał-gubernatora postanowiła kontrolować ten problem. Dodatkowo ministerstwo dóbr państwowych, w przedstawianych w 1864 r. cesarzowi raportach poświęconych guberniom zachodnim Imperium, podkreślało, iż jednym ze skutków działań zbrojnych prowadzonych na tych terenach w czasie powstania styczniowego, był niezadawalający stan rozwoju ekonomicznego Kraju Zachodniego, na którego obszarze jaskrawo widoczny był brak kapitału inwestycyjnego. W planach rządowych, jednym ze sposobów zaradzenia temu zjawisku miało być wsparcie rządowe dla osadników przybywających do guberni zachodnich. Kierując się uwagami podnoszonymi przez Michaiła Murawjowa, a przede wszystkim opiniami płynącymi z raportu ministra Aleksandra Zielenoja z dnia 23 marca 1864 r., Aleksander II postanowił, aby w przypadku nabywania przez ludność osiedleńczą nieruchomości, stosowane były rozwiązania przedstawione przez ministerstwo dóbr państwowych. Przewidywały one potrzebę niezwłocznego utworzenia specjalnego funduszu pożyczkowego, z którego udzielane byłyby kredyty na zakup gospodarstw rolnych ${ }^{112}$.

110 Wysoczajsze utwierżdiennoje w 5 dien marta 1864 goda polożenije o lgotach, prieimuszczestwach i dienieżnych ssudach, predostawliajemych pri pokupk kaziennych i czastnych imienii w Zapadnych gubierniach, [w:] Sbornik prawitielstwiennych rasporjażenij po wodworieniju ruskich..., s. $11-12$.

${ }^{111}$ Lietuvos Mosklų Akademijos Vrublevskių Biblioteka, Wilno, sygn. F9-2660, rkps, T. Wróblewski, Zbiór ustaw cywilnych. Przekłady ustaw cywilnych. Kolekcja ogólna, k. 80; zob. też: W. Grabski, Materiały w sprawie włościańskiej, t. I, Warszawa 1907, s. 63.

${ }^{112}$ Ukaz Prawitelstwujuszczago Senata ot 3 aprila 1864 goda, [w:] Sbornik prawitielstwiennych rasporjażenij po wodworieniju ruskich..., s. 18-19. 
Michaił Murawjow, oceniając swą polityczną działalność w podległych mu guberniach, twierdził, iż kierowana przez niego administracja podjęła skuteczne działania w zakresie ustroju agrarnego tych ziem, a przede wszystkim potrafiła ona objąć opieką rządową przedstawicieli ludności włościańskiej. W tym kontekście Murawjow uznał za słuszne wydanie ukazu z 1 marca 1863 r., który jego zdaniem przyśpieszył pracę komisji weryfikacyjnych i doprowadził do „całkowitego wygaśnięcia wszystkich obowiązujących stosunków między chłopami a byłymi ich ziemianami"113. Działania podejmowane przez władze rosyjskie w praktyce usprawiedliwione były przyjętymi celami, które należało dostosowywać do miejscowych warunków. Michaił Murawjow, który za swą służbę w guberniach północno-zachodnich otrzymał rosyjski tytuł hrabiowski, postrzegał w tym kontekście, antagonizujące na tym obszarze ziemiaństwo i ludność włościańską odrębności lingwistyczne i konfesjonalne. Przedstawiając opinię na temat relacji łączących obie te grupy społeczne, podkreślił, iż wskazane dyferencjacje, a także nieurodzajna w niektórych powiatach gleba, nietolerancja religijna miejscowej szlachty czy też ignorowanie przez jej przedstawicieli potrzeb ludu wiejskiego, takich jak krzewienie prawidłowych postaw moralnych i wiedzy wśród chłopów, mogło skutkować wystąpieniem trudności związanych z wypełnianiem postanowień reformy z $1861 \mathrm{r}$. znoszącej poddaństwo ${ }^{114}$. Ponadto proces realizacji reformy włościańskiej zakłócały także przejawy współpracy ludności żydowskiej i miejscowego ziemiaństwa, którego reprezentanci mieli ,oddawać chłopów jako stałych robotników"115.

Generał-gubernator wileński, oceniając skutki pierwszych działań podjętych przez administrację rządową na rzecz ludności osadniczej, zauważył dość szybko pojawiające się niebezpieczeństwa i niepowodzenia. Michaił Murawjow, definiując grupę ,polskiej inteligencji”, do której zaliczał szlachtę i kler rzymskokatolicki, przypisał jej zrazem destrukcyjne cechy: demokratyczności, legalności oraz zależności od prądów liberalnych. Z kolei te przesłanki mogły skutkować przeszczepieniem radykalno-anarchistycznych pierwiastków w tkankę społeczną, jaką była grupa ludności napływowej. Obserwując zagrożenia polegające na asymilacji przez zarówno niektórych osadników, jak i urzędników rosyjskich miejscowych zwyczajów i zasad, był przekonany, iż zarówno on, jak i jego następcy, powinni być ostrożnymi i działać z rozmysłem przy osiedlaniu ,obywateli ziemskich w Kraju Zachodnim". Z prakseologicznego punktu widzenia Murawjow uznał również za niezbędne: ,[...] osiedlać ich nie jako oddzielnych posiadaczy ziemi, niemających

${ }^{113}$ LVIA, sygn. F. 439, ap. 1., b. 56, rkps, Dokładnaja zapiska M.N. Murawjowa cariu o prowiedienii kriestianskoj rieformy w Siewiero-zapadnom kraje $1865 \mathrm{~g}$, Wilno 1865 [brak daty dziennej]. Kolekcja muzeum i archiwum hrabiego Michaiła Murawjowa, k.1.

${ }^{114}$ Ibidem, k. 1v.

115 Ibidem, k. 2. 
między sobą łączności, lecz o ile możności ich ugrupować w najbliższych między sobą miejscowościach. W przeciwnym bowiem razie rozporządzenia rządowe co do osiedlenia żywiołu rosyjskiego w kraju nie doprowadzą do celu, jak to pokazało doświadczenie kolonizacji za czasów Katarzyny [II - M.T.] i Aleksandra I" 116.

Michaił Murawjow posiadający w czasie trwającego na ziemiach litewsko-białoruskich powstania silną pozycję, realizował politykę nakierowaną na stłumienie „buntowniczego zrywu”, objawiającą się silnymi represjami, skierowanymi przeciwko mieszkańcom podległych sobie guberni. Nie mniej ważną, obok głównych celów politycznych, kwestią pozostawała sprawa chłopska, a także akcja osiedleńcza ludności pochodzącej z guberni wewnętrznych rosyjskiego Imperium. Oba, uwzględniane przez Murawjowa w jego politycznej aktywności zagadnienia, stanowiły środek sprzyjający realizacji planu ,uratowania Litwy dla Rosji" ${ }^{117}$. Co wydaje się równie istotne, Michaił Murawjow wykonujący, jak sam określał w cytowanych już Pamiętnikach, relewantną misję ${ }^{118}$, spotkał się z poparciem niektórych reprezentantów elity intelektualnej ówczesnego Cesarstwa. Jego decyzje aprobował bowiem przykładowo Nikołaj Niekrasow ${ }^{119}$, a zatem przedstawiciel rozwijającego się w warunkach samodzierżawia liberalizmu w szerokim i specyficznym rosyjskim ujęciu - odrzucającym wszelkie przejawy radykalizmu społecznego oraz koherentnym w swych założeniach z fundamentami, na których opierała się imperialna państwowość ${ }^{120}$. Opinia ta nie oznacza bynajmniej, iż Michaiła Murawjowa można zaliczyć do grona rosyjskich dziewiętnastowiecznych liberałów. Pozwala ona jednak wyrazić przekonanie, iż poparcie dla aktywności politycznej wileńskiego generał-gubernatora, płynęło z różnych politycznych środowisk rosyjskich, niezależnie od ich postaw ideowych.

\section{THE ORIGINS OF THE POLICY OF COUNT MIKHAIL NIKOLAYEVICH MURAVYOV, THE GOVERNOR GENERAL OF VILNIUS, IN RELATION TO THE ISSUES OF THE PEASANTRY AND OF THE RUSSIAN SETTLEMENT IN LITHUANIA (1863-1865)}

\section{Summary}

The article contains a description of the characteristics of the legal acts devoted to the status of the peasant population and of the settler population in the northwestern governorates of the Russian Empire between 1863 and 1865. The rule of Mikhail Muravyov, the governor general of Vilnius, was a significant period. In the duration of his rule, the

\footnotetext{
116 Cyt. za: M. Murawjow, Pamiętniki Michała Mikołajewicza..., s. 156-157.

117 S. Tarnowski, Przedmowa wydawców, [w:] ibidem, s. 13.

118 M. Murawjow, Pamiętniki Michała Mikołajewicza..., s. 152.

119 A. Spekke, History of Latvia. An outline, [Ryga] 2006, s. 278.

120 A. Walicki, Filozofia prawa rosyjskiego liberalizmu, Warszawa 1995, s. 66.
} 
Russian administration repeatedly undertook steps to realize the Emancipation Reform of $19^{\text {th }}$ February 1861, while also taking into consideration the events connected with the January Uprising. To that end, political actions were undertaken as well as various types of legal acts were passed in relation to the peasant population. Moreover, this group was considered to a large degree to be "indigenously Russian" according to the local authorities. It was supposed to be a social stratum, together with the practically and legally supported group of settlers from the governorate from the interior of the Empire, used to politically and economically weaken the nobility which occupied the Northwestern Krai.

\section{LES ORIGINES DE LA POLITIQUE DU GOUVERNEUR GENERAL DE VILNIUS LE COMTE MICHAIL NIKOLAJEWICZ MURAWIEW ENVERS LA QUESTION PAYSANNE ET LA COLONISATION RUSSE EN LITUANIE (1863-1865)}

\section{Résumé}

L'article contient la caractéristique des actes juridiques concernant le statut de la population paysanne et de la population de colons dans les gouvernements (goubernia) nord - ouest de l'Empire russe dans les années 1863-1865. L'administration du gouverneur général de Vilnius Michaił Murawiew constituait une période significative pendant laquelle l'appareil administratif russe tentait, compte tenu des événements liés au soulèvement de Janvier, de réaliser la réforme paysanne du 19 février 1861. Dans ce but, des actions politiques et des actes juridiques de tous types ont été appliqués à la population paysanne qui, par les autorités locales, était majoritairement considérée comme «russe de souche». Elle devait constituer, avec un groupe de colons soutenus en fait et en droit originaires des gouvernements intérieurs de l'Empire, une couche sociale utilisée pour fragiliser la situation politique et économique des nobles habitant sur les terrains de la Russie Nord-Ouest. 
